\title{
Intercontinental Transport and Climatic Impact of Saharan and Sahelian Dust
}

\author{
N'Datchoh Evelyne Touré, Abdourahamane Konaré, and Siélé Silué \\ Laboratoire de Physique de l'Atmosphère, Université de Cocody, 22 BP 582 Abidjan 22, Cote d'Ivoire \\ Correspondence should be addressed to N’Datchoh Evelyne Touré, ndatchoheve@yahoo.fr
}

Received 30 December 2011; Revised 15 May 2012; Accepted 31 May 2012

Academic Editor: Dimitris G. Kaskaoutis

Copyright ( $) 2012$ N’Datchoh Evelyne Touré et al. This is an open access article distributed under the Creative Commons Attribution License, which permits unrestricted use, distribution, and reproduction in any medium, provided the original work is properly cited.

\begin{abstract}
The Sahara and Sahel regions of Africa are important sources of dust particles into the atmosphere. Dust particles from these regions are transported over the Atlantic Ocean to the Eastern American Coasts. This transportation shows temporal and spatial variability and often reaches its peak during the boreal summer (June-July-August). The regional climate model (RegCM 4.0), containing a module of dust emission, transport, and deposition processes, is used in this study. Saharan and Sahelian dusts emissions, transports, and climatic impact on precipitations during the spring (March-April-May) and summer (June-JulyAugust) were studied using this model. The results showed that the simulation were coherent with observations made by the MISR satellite and the AERONET ground stations, within the domain of Africa (Banizoumba, Cinzana, and M'Bour) and Ragged-point (Barbados Islands). The transport of dust particles was predominantly from North-East to South-West over the studied period (2005-2010). The seasonality of dust plumes' trajectories was influenced by the altitudes reached by dusts in the troposphere. The impact of dusts on climate consisted of a cooling effect both during the boreal summer and spring over West Africa (except Southern-Guinea and Northern-Liberia), Central Africa, South-America, and Caribbean where increased precipitations were observed.
\end{abstract}

\section{Introduction}

Numerous studies have been focused on Sahelian climate variability contrary to the tropical humid African areas for which reliable data do not exist. Servat et al. [1] showed that the tropical humid belt has been similarly affected by series of climatic episodes in comparison with those observed in the Sahelian zone. In addition, this region has been subjected to significant environmental changes due to the increase of populations and strong exploitation of natural resources such as deforestation [2]. Furthermore, this region is particularly rich in aerosols from various origins leading to coexistence in the region of maritime, desert, urban, and bushfire aerosols. Besides, the plumes of desert and Sahelian dusts ejected into the atmosphere during emission episodes are an integral part of the West African climate system [35]. The greater part of mineral aerosols is emitted from arid and semiarid zones on the Earth where, these surfaces are less protected from erosion because of very limited or inexistent vegetative covers, and of very low soil humidity limiting the cohesion of constituent elements [5]. Thus, the Saharan-Sahelian region has been identified as the world's first source of emission of this aerosol type [6-9]. Recent studies have made it possible to identify the most active zones in this part of the world. They revealed four major emission sources, that is, the Bodélé region, the Nubian Desert, the Libyan Desert, and the zone covering Mauritania, Mali, and Southern Algeria [10-12]. The particles, once in the troposphere, can be transported over long distances beyond the African continent. The meteorological conditions in the Sahara and surrounding region will determine the dust plume transportation characteristics (i.e., direction, speed, altitudes, trajectories, distance travel, and duration of transport). Three main trajectories for Saharan and Sahelian dust transportation have been identified, and these include the transatlantic transport toward the Gulf of Guinea, United States of America, Caribbean Island, and South America $[8,13,14]$, the transport towards the Mediterranean and 
towards Europe $[15,16]$, and finally the transport towards Near East and Middle East [17]. A transcontinental transport of aerosol plumes from North Africa to Japan via the Middle East and southern Asia has been suggested by Tanaka et al. [18]. For D'Almeida [13], 60\% of Saharan and Sahelian dusts are transported towards the Gulf of Guinea, 28\% towards the Atlantic Ocean and 12\% towards Europe. Satellite observations and direct measurements have shown that the dust plume transportation over the Arabic Peninsula, NearEast, and Middle East, is essentially responsible for the dust plume coming from Eastern Sahara (Libya, Egypt, and Sudan) [19]. This transportation is significant during three periods in the year [17], namely, the spring (March to May), the summer (July to August), and autumn (September to November).

The dust particles may also influence the local atmosphere by absorbing and reflecting solar radiations that modify the radiation toll of the atmosphere and the Earth surface $[20,21]$. Their impact on the global radiation budget still remains the big uncertainty that affects the ability of models to predict climatic change [22]. However, some modeling based-studies showed that Saharan and Sahelian dusts can affect the West African monsoon [23-26]. Although all these studies agree on the fact that dusts have impact on West Africa, they did not agree on the associated atmospheric answers such as the increase and decrease of precipitations over the Sahelian region. Indeed, while Konaré et al. [24] and Solmon et al. [25] have shown that they induce a decrease in precipitations over the Sahelian band, Lau et al. [23] and Kim et al. [27] agreed on the fact that an increase of heat in the higher layers of the troposphere induces an adiabatic warming which, causes an increase of precipitations. Such a controversy perfectly illustrates the complexity of "aerosol-climate" interactions, as well as the necessity of taking them into account in climate prediction models, and the West African climate in particular. However, most of these studies were focused on the monsoon period and very few were concerned about the transitional period (March-April-May), even though intensive events of dust emissions often occur during this period (e.g., during the spring 2010).

This paper presents (1) an interseasonal analysis of dust transport from the African continent to the American coasts using regional climatic modeling and (2) assesses the impact of their radiation and associated effects during the transport with specific focus on events of the spring 2010.

\section{Methodology and Data Collection}

The regional climate model, RegCM 4.0, designed by the International Centre of Theoretical Physics (ICTP) in Italy, was used to do the climate simulations based on the method used by Giorgi et al. [28] and Pal et al. [29]. A dust particle module was incorporated in the version 3.1 of this model by Zakey et al. [30]. Since then, several studies on dusts have been made using the model [24, 25, 31]. The weekly data of the Optimum Intertropical Sea Surface Temperature (OISST) of the National Center for Environmental Prediction (NCEP) for the values of the Sea Surface Temperature
(SST), as well as the reanalysis data of the NCEP, were used as initial meteorological conditions while forcing the model during the simulations. Soil humidity was initialized under standard conditions of the model (RegCM) as defined by Giorgi and Bates [32]. The surface conditions and soil types used in the model were from Dickinson et al. [33] and Zobler [34], respectively. RegCM4.0 uses the radiation scheme of the NCAR CCM3, which is described in Kiehl et al. [35]. Briefly, the solar component, which accounts for the effect of $\mathrm{O}_{3}$, $\mathrm{H}_{2} \mathrm{O}, \mathrm{CO}_{2}$, and $\mathrm{O}_{2}$, follows the $\sigma$-Eddington approximation of Kiehl et al. [35]. It included 18 spectral intervals from 0.2 to $5 \mu \mathrm{m}$. The simulations were done between November 2004-December 2010, with $48 \times 168$ grid points, at the spatial resolution of $60 \mathrm{~km}$ and 18 pressure levels. To validate the simulations, available observation data from Aerosol Robotic NETwork (AERONET) on the Barbados station and data from three African stations (Banizoumbou in Niger, Cinzana in Mali, and M'Bour in Sénégal) were used. In addition, monthly observation data from Terra Multiangle Imaging Spectro-Radiometer (MISR) at the spatial resolution of $0.5 \times 0.5$ degrees were used to validate the monthly mean Aerosol Optical Depth (AOD) values over the whole domain of the simulations. The domain was chosen in manner that the particle sources, transports, and depositional processes from Africa to America could be captured in the simulations. In order to study the climatic impacts, two simulation types were done. While the first type considered dust particles, the second did not.

\section{Results and Discussion}

3.1. Comparison between Model and Observations. The simulations made with the climate model, RegCM 4.0, between November 2004-December 2010, showed that the model perfectly simulated the different dust emission sources in the North Africa. The four major sources (the depression of Bodélé, the Nubian Desert, the Libyan Desert, and the zone covering Mauritania, Mali, and Southern Algeria) $[11,12]$ were well captured (Figures not shown). Figure 1 shows the comparison between the monthly mean emissions of March, April, and May 2010 from the model and those of the available observations from Terra MISR at the resolution of 0.5 $\times 0.5$ degrees. It appeared that the model properly captured the dust emissions of April and May (Figures 1(c), 1(d), 1(e), and 1(f)). However, values from the MISR observations were lower than the simulated results. The lower values of the observation could be due to the fact that closer to the sources, substantial amounts of dust present in the lowest atmospheric layers (below $1 \mathrm{~km}$ ) could not be detected by the satellite [24]. In contrast, great differences were found between the observations and the model simulations for the emissions in March, 2010 (Figures 1(a) and 1(b)). These differences may be attributed to emissions from biomass fires that were not taken into account in these simulations. This month (March) coincided with the end of the fire season in this part of the Northern Hemisphere. The model captured well the AOD values in the absence of burning practices in West Africa during the months of April and May. 


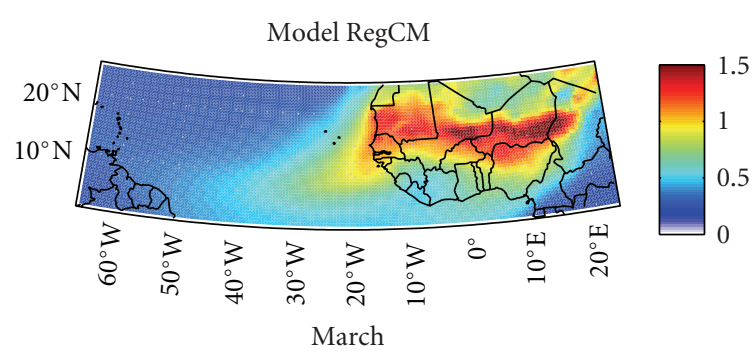

(a)

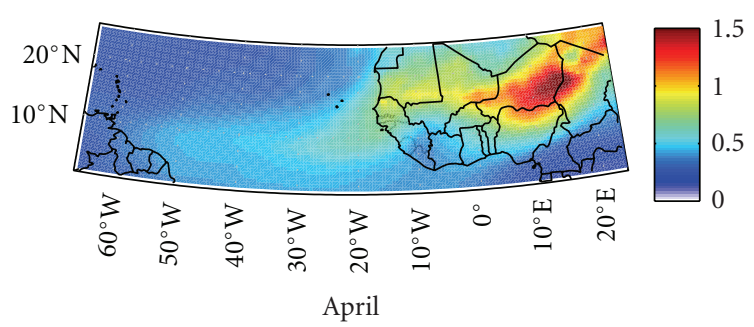

(c)

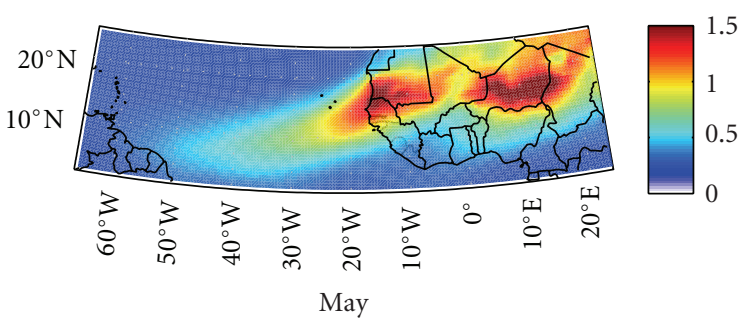

(e)

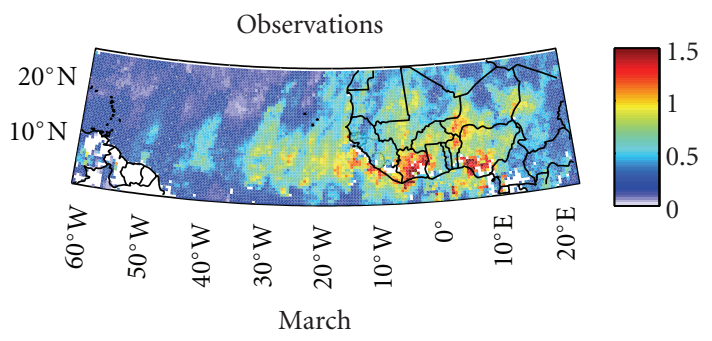

(b)

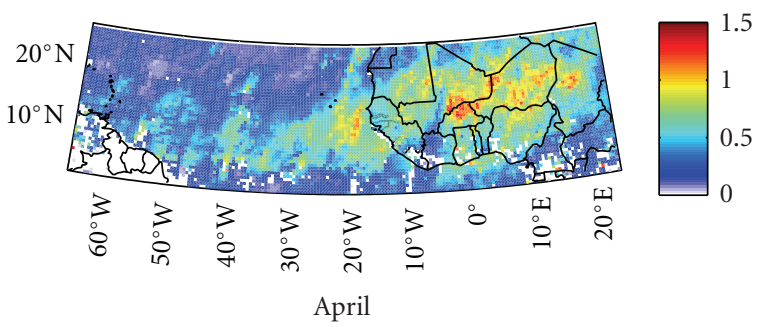

(d)

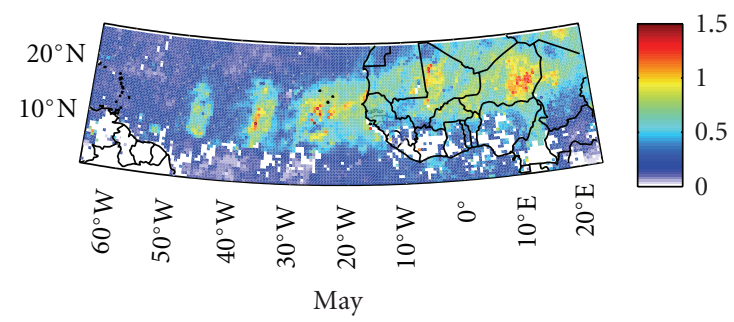

(f)

FIGURE 1: Comparison of monthly mean values of AOD during the year 2010: (a) RegCM for March, (b) MISR observations for March, (c) RegCM for April, (d) MISR observations for April, (e) RegCM for May, and (f) MISR observation for May.

However, dust sources were more extended in the model than in the observations, and these were coherent with the results from Konaré et al. [24] obtained with the version 3 of the same model. Therefore, compared to the MISR observations, the model tends to overestimate the AOD in the areas of maximum dust sources. On the other hand, close to these sources substantial amounts of dusts were present in the lower atmospheric layers (below $1 \mathrm{~km}$ ), which present difficulties for satellite retrieval and hence not detected in the MISR data. The Bodélé Sahel was the most active region during the spring of 2010 .

3.2. Dust Episodes during March 2010. This study was focused on March 2010 as a continuation of observations made at the four stations (Banizoumbou, Cinzana, and M'Bour). Modeling data obtained revealed intensive dust emission episodes for March 2010. Two important emission events were simulated by the model over Niger that has been previously identified as sources by N'Tchayi et al. [36]. The first event occurred during the first 10 days of the month (precisely during March 5-8th), whereas the second took place between the 17th and 21st of March (Figure 2).

The comparison between AOD values reproduced during these two events with the model and those found by AERONET at the three African stations (Banizoumba, Cinzana, and M'Bour) indicated significant dust emissions (Figure 3). However, at the Banizoumba station, the model captured the first peak of March very late. In addition, observations from the stations confirmed that the AOD values were well detected in the model simulations both in terms of magnitude and variability. The second event (17th to 21st March) was well captured by the model than the event of 5th to 8th March. However, the AOD values detected with the model were slightly underestimated compared to the observed values. This underestimation might be explained firstly, by the overestimation of the duration of events (i.e., dust emissions), which was illustrated by the widening of peaks (Figure 3) and, secondly, by the interpolation method to estimate the mean of AOD values from the model.

3.3. Temporal Evolution of Dust Plumes. Although the model takes into account the emission and transport of dusts at a time, in this section we focused on dust transport in March 2010. The transportation of dust was observed from the African continent towards the Atlantic Ocean (from NorthEast towards South-West) (Figures 4, 5, and 6). A maximum dust plumes seen on March 6th over Mauritania and Senegal was found on March 7th over Senegal and Gambia. Then, 


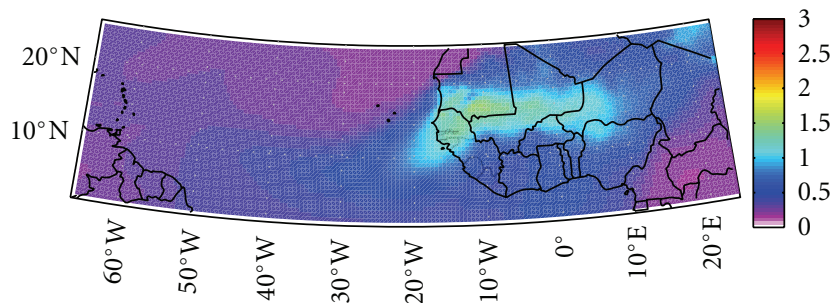

(a)

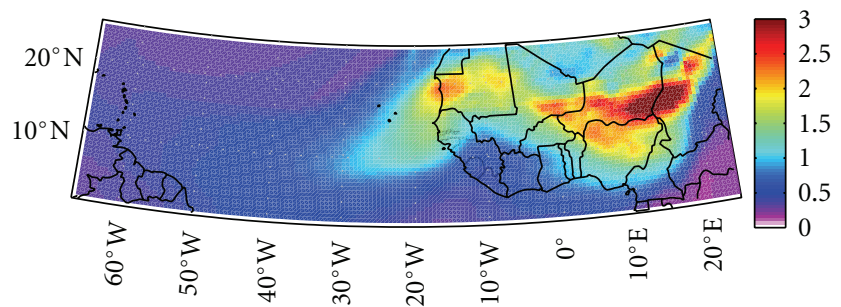

(b)

Figure 2: Mean AOD values during dust episodes simulated with the RegCM 4.0: (a) March 5-8 and (b) March 17-21.

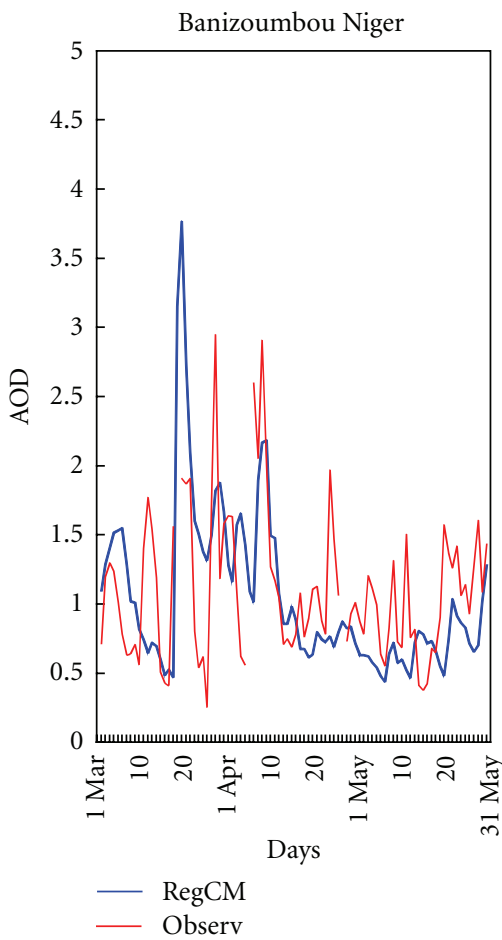

(a)

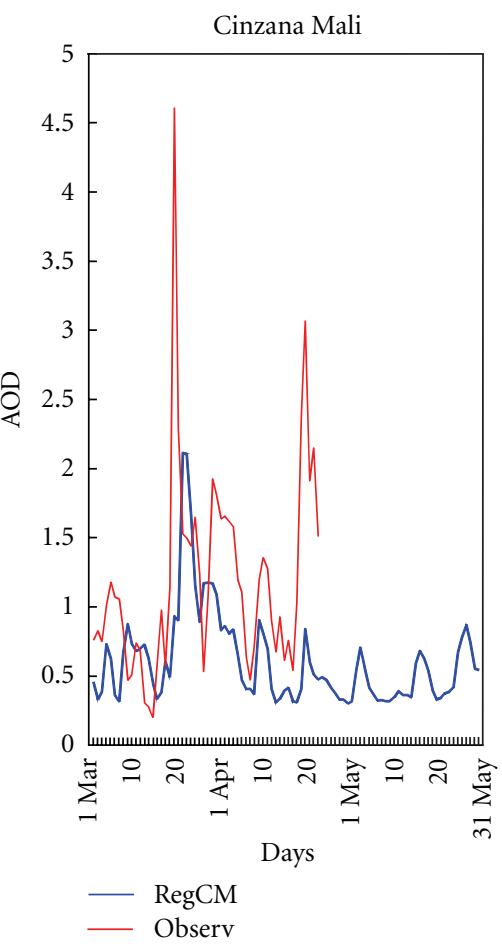

(b)

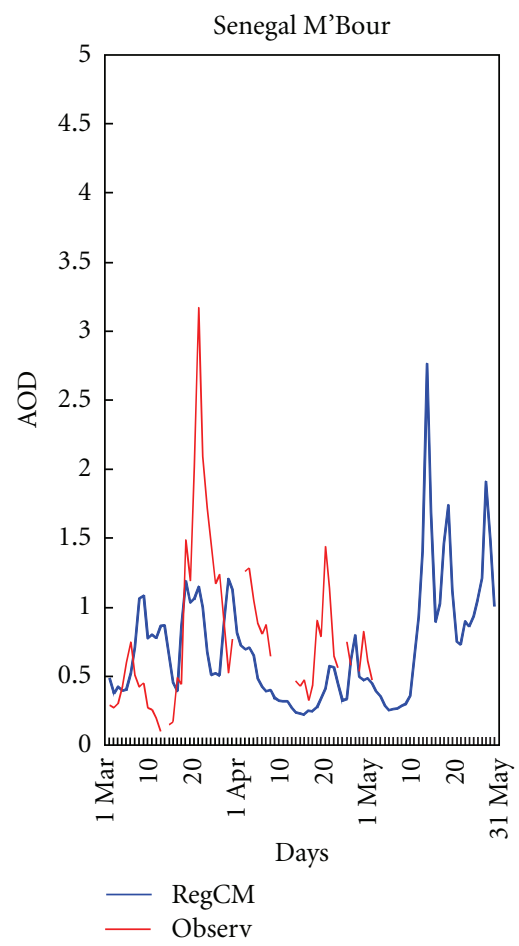

(c)

FIgure 3: Comparison of AOD values between the RegCM 4.0 simulations and the observations made with the AERONET at $500 \mathrm{~nm}$ (from March to May 2010).

this continued to the Ocean beyond the Guinean Coasts on March 8th (Figure 4), before being entirely present over the Atlantic Ocean on March 9th. Dust plumes became less concentrated during the transport as a result of deposition. Thus, the particles emitted on March 6th spent 3-5 days to pass through the continent to the Atlantic Ocean (Figure 4). In contrast with these two periods, dust events on the 17th to 21st of March seemed stronger (Figure 5). In fact, the Chad and Niger sources were active simultaneously during the first three days (19th, 20th, and 21st of March) in the way that the spatial evolution was more accentuate than the temporal evolution. This may be attributed to the fact that the model captured well the events of 17th to 21st of March than that of the 5th to 8th of March. Similar paths were found for dust emissions occurring in April and May (i.e., from North-East towards South-West). This direction, as revealed in Figures 4, 5, and 6 for the period March-May, was shown by previous studies, which suggested that dust transport from the African continent was seasonal following three trajectories: (i) the transatlantic trajectory towards the USA, Caribbean Islands, and South America [8, 15, 37], (ii) the transport towards the Mediterranean and Europe [16], and (iii) the transport to the Near East and Middle East [17]. Thus, dusts emitted from Sahara and Sahel can reach the West Indies during the summer [17], whereas during the spring, they are transported through South America to the Amazonian basin and eastern Mediterranean [8, 38].

The transatlantic trajectory of dust particles is known to be influenced by the Inter-Tropical Convergence Zone (ITCZ) $[39,40]$. This trajectory is influenced by the different mechanisms of dust plume rising in the atmosphere linked to monsoon flow. The convergence of Harmattan and monsoon 


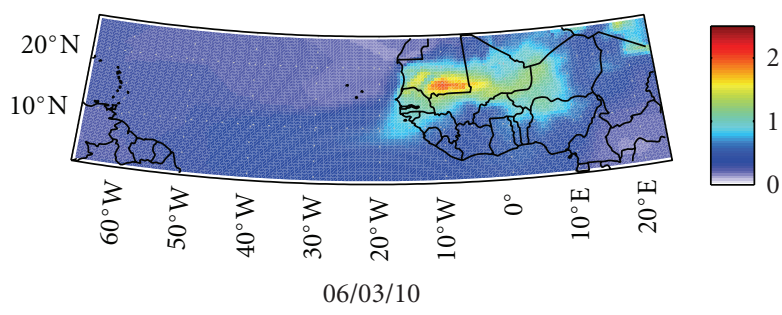

(a)

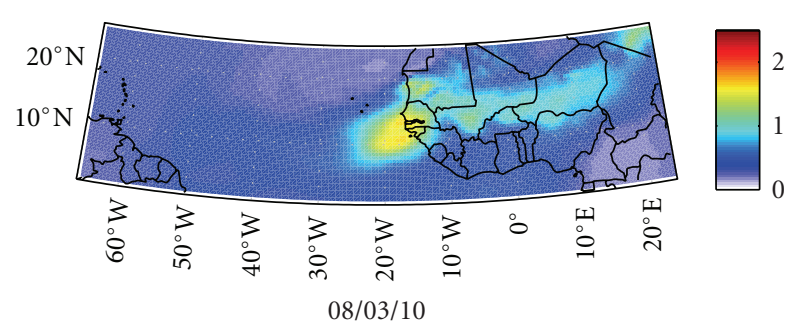

(c)

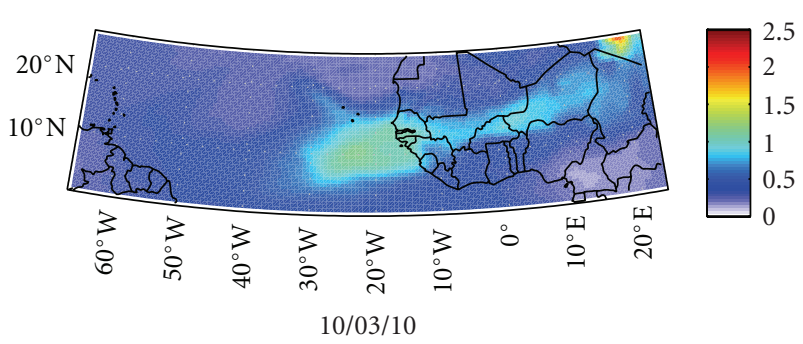

(e)

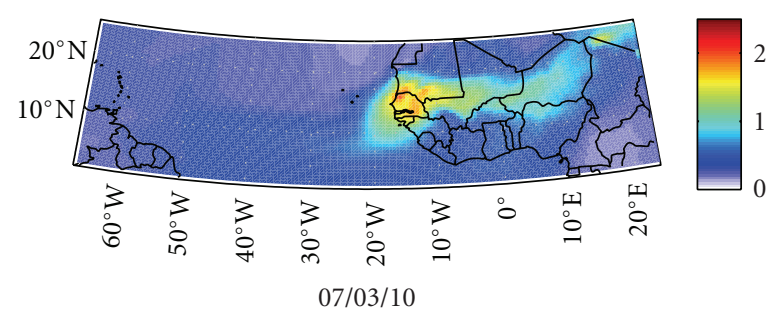

(b)

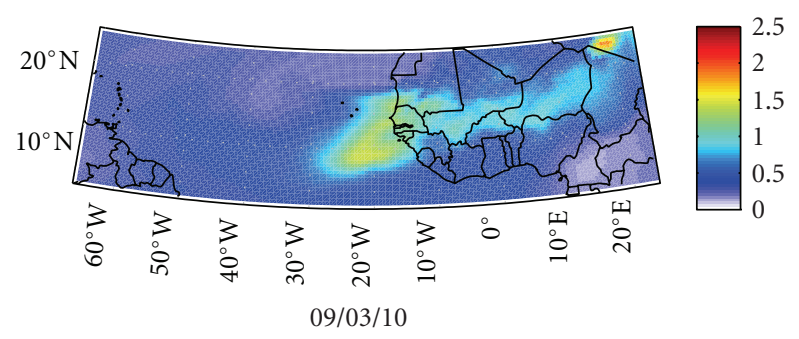

(d)

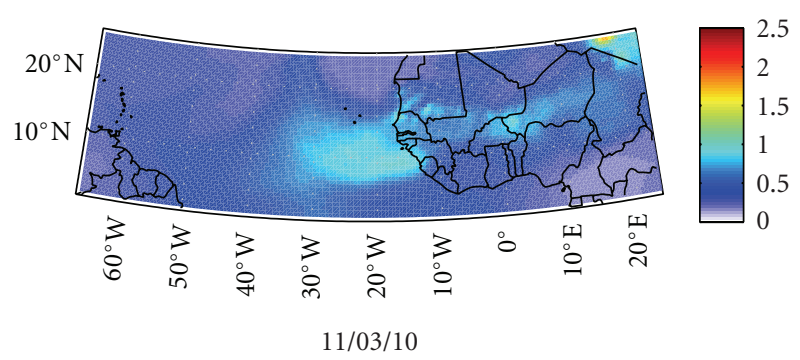

(f)

FIGURE 4: Evolution of dust particles (episode of March 5-8th simulated with the RegCM 4.0) from the African continent towards the Atlantic Ocean between March 6-11th 2010.

wind in the low pressure zone in the ITD (InterTropical Discontinuty) constitutes a favorable condition for the establishment of strong wind on either side of the ITD favoring the rising of the dust plumes $[39,40]$. The directions of the dust plumes vary with the seasons linked to the ITD and the dust rising mechanisms that is governed by the West Africa Monsoon system. It is also modulated by the activity of the East African Waves (EAW), which spread from East to West [41-44]. These transport features are satisfactorily captured by the Model. Jones et al. [43] showed that $20 \%$ of dust particles ejected into the atmosphere over the major part of North Africa were associated with EAW. They suggested that EAW must have regulated the suspension of Saharan and Sahelian dust in the atmosphere. Also, 10-20\% of dust seasonality concentrations over North Atlantic Ocean were linked to EAW, an indication of the modulation of dust transport by the EAW.

3.4. Dust Detection in Barbados' Islands. Studies have shown that dust particles may be detected by the AERONET in the Caribbean Island and on the American coasts [8]. We, therefore, compared the simulated AOD to those of the AERONET Ragged-point station located in the Barbados Island, with the aim of bringing out the particularity of emissions of spring 2010, in spite of the missing observational data. The AOD values were comparable to those of the Barbados Islands, although spring was not the season of maximal detections of Saharan and Sahelian dusts in the Island. Thus, monthly AOD values found at the Raggedpoint station during the months of March-April-May from 2008 to 2010 showed that the most elevated values (more than double of values observed in 2008 and 2009) were registered during March and April 2010 (Table 1). The AERONET observational AOD values showed that the mean value of March and April of 2010 was more than doubled that of March and April of 2008 and 2009 at the same station. In addition, the values registered during spring 2010 (at $500 \mathrm{~nm}$ ) were in the same order as the monthly mean values at $870 \mathrm{~nm}$, observed during the boreal summer where Saharan and Sahelian dust plumes got to the Barbados Islands in their maximal quantities [45].

The model satisfactorily reproduced the variability in most of the peaks observed by AERONET measurements (Figure 7). However, dust emissions occurring during the first 10 days of March 2010 were not detected by the model.

3.5. Zonal and Meridian Transport of Dust. Dust particles are present in the West African environment and interact 


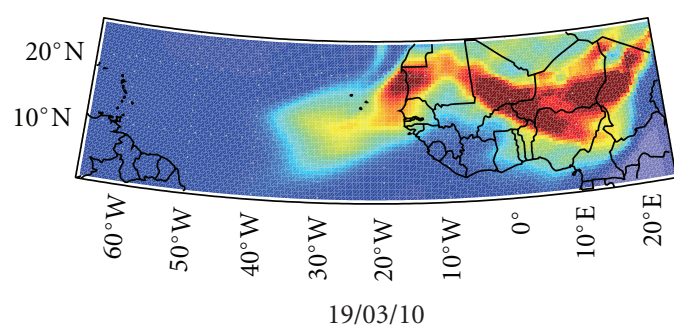

(a)

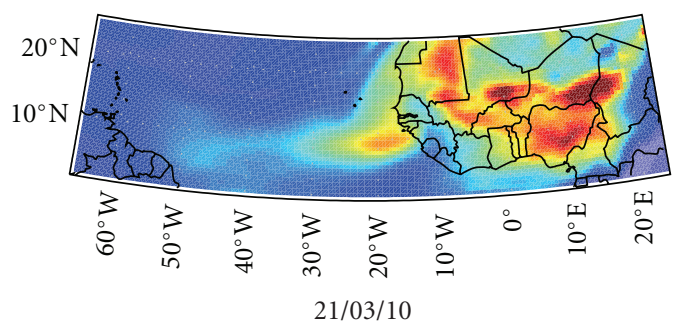

(c)

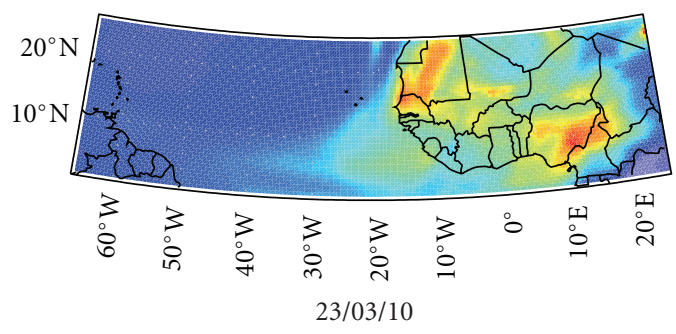

(e)
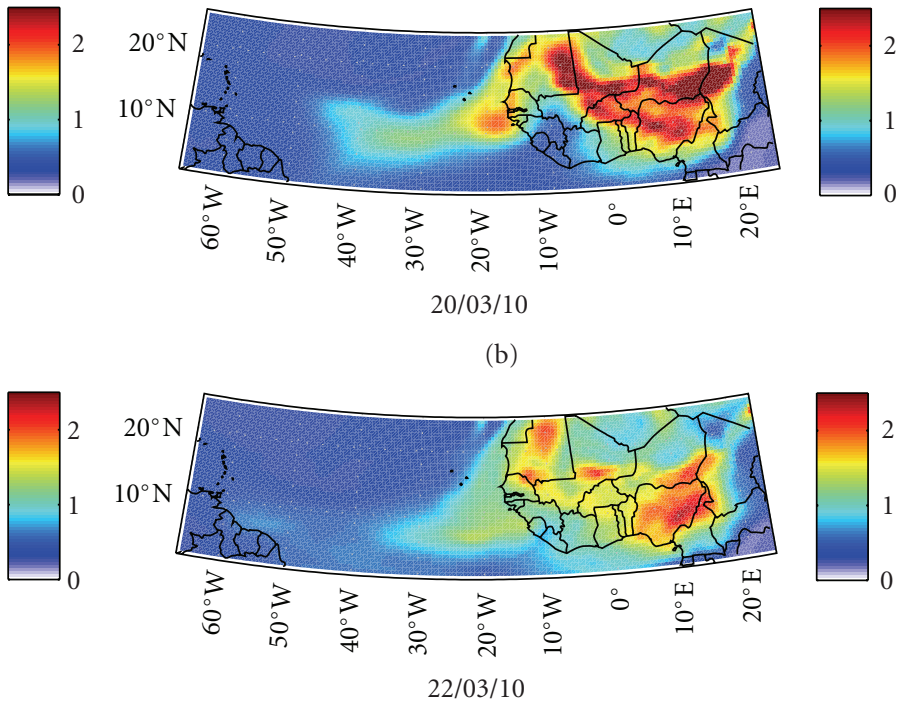

(d)
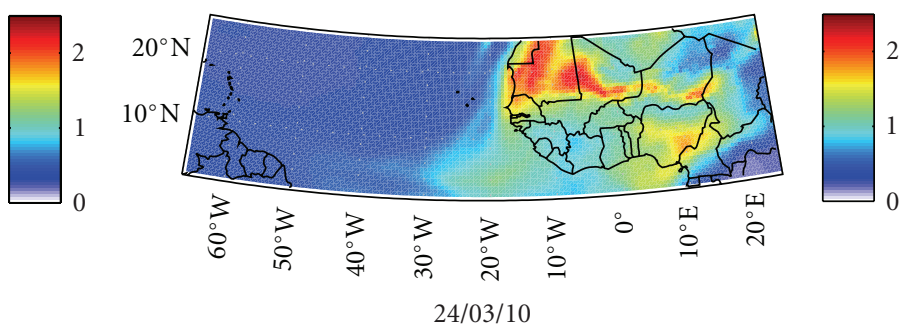

(f)

Figure 5: Evolution of dust particles (episode of March 17-21st, simulated with the RegCM 4.0) from the African continent towards the Atlantic Ocean between March 19-24th 2010.

TABle 1: Comparison between monthly AOD values (at $500 \mathrm{~nm}$ ) simulated with the RegCM 4.0 and monthly values observed at the Ragged-point station (Barbados).

\begin{tabular}{llll}
\hline & 2008 & 2009 & 2010 \\
\hline $\begin{array}{l}\text { March } \\
\text { RegCM }\end{array}$ & 0.11 & 0.14 & 0.21 \\
$\quad$ Observation & 0.09 & 0.08 & 0.19 \\
$\begin{array}{l}\text { April } \\
\quad \text { RegCM }\end{array}$ & 0.15 & 0.17 & 0.21 \\
$\quad$ Observation & 0.18 & 0.09 & 0.31 \\
May & & & \\
$\quad$ RegCM & 0.19 & 0.22 & 0.18 \\
$\quad$ Observation & 0.16 & 0.23 & 0.24 \\
\hline
\end{tabular}

with climate processes. Hence, they constitute an integral component of climate systems over this region. They were present in all the study areas and their concentrations progressively decreased as they moved away from their sources due to the deposition processes, which are various and cover large part of the globe with some preferential sites such as the tropical forest [8], monsoon zone [46], and the Oceans [47].
Meridional profile section (Figure 8) revealed that dust sources are located between $18^{\circ} \mathrm{N}$ and $22^{\circ} \mathrm{N}$. The dust source around $18^{\circ} \mathrm{N}$ (Bodélé) possessed a quasicontinuous activity that is, during the three periods December-JanuaryFebruary (DJF), March-April-May (MAM), and June-JulyAugust (JJA) with the most intensive activity occurring at DJF and MAM. During the dry season (DJF), the dusts were mostly observed in the lower troposphere where they essentially spread from the continent towards the West and from the North towards the South. During the period, MAM, they reached higher altitudes than that of DJF with elevated concentrations towards the South. During the boreal summer, there were not only elevated concentrations but also vertical rising of dust particles. This result was consistent with Chiapello et al. [48], who showed that during summer, dust particles are transported into higher altitudes than in winter. Between $1^{\circ} \mathrm{W}$ and $7^{\circ} \mathrm{E}$, a vertical rising of dusts towards the highest atmospheric strata appeared during the period MAM (Figure 9). This may be due to the existence of a thermal anomaly, which could favor a vertical rising of dust particles. Thus, the period MAM could be a transition between the periods DJF, where the altitudes reached were minimal and JJA showing maximal altitudes. The altitudes reached during MAM were also transitional between those of DJF (low altitudes) and JJA (high altitudes). 


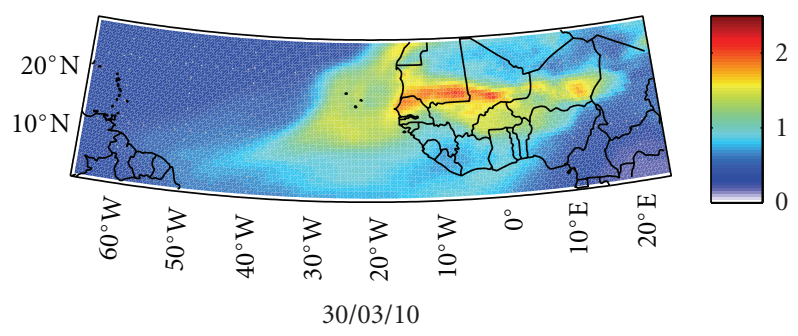

(a)

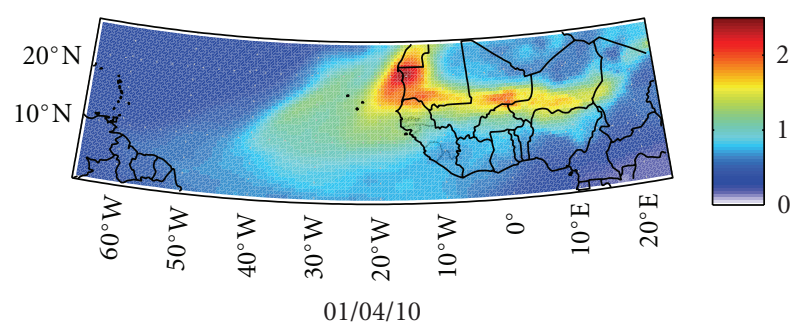

(c)

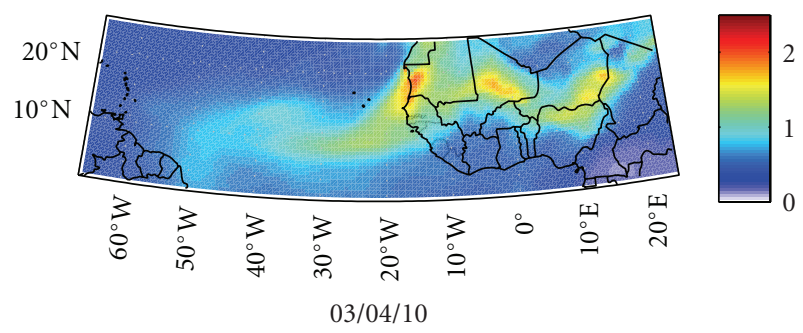

(e)

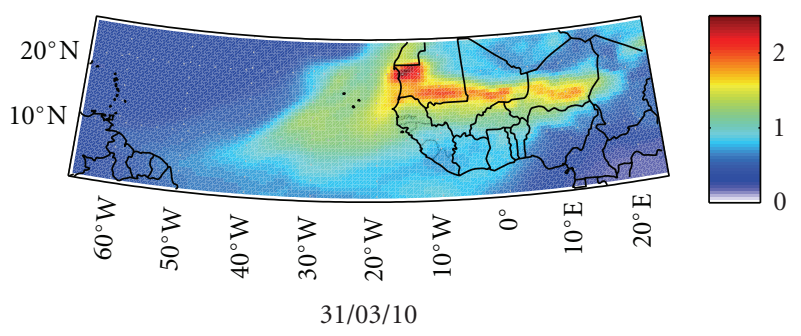

(b)

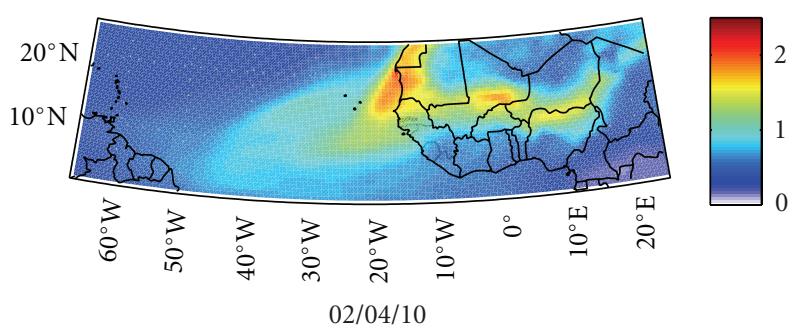

(d)

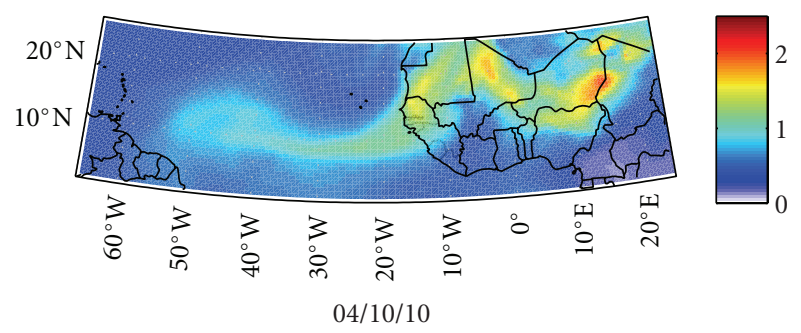

(f)

Figure 6: Evolution of dust particles from the African continent to the Atlantic Ocean, simulated with the RegCM 4.0 between March 30 th and April 4th 2010.

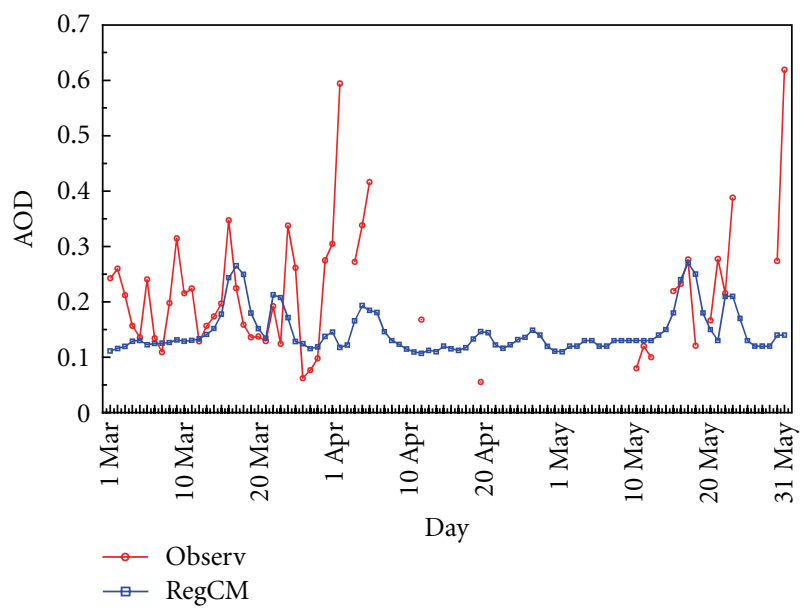

FIGURE 7: Daily simulated AOD values at the Ragged-point station, during March-April-May 2010 with the RegCM 4.0 and observations from AERONET.

The altitudes reached by the dust particles strongly impacted the trajectories of dust plumes and therefore have to be taken into account when studying the transport of dust plumes over the Atlantic Ocean. In effect, these altitudes can vary according to the season and the dust concentrations decrease progressively when they are transported from their sources towards the coasts due to the deposition processes. Dust transport is obviously strongly influenced by the regional atmospheric dynamic. Otherwise, the importance of dust concentrations in the low atmospheric strata and their propagation at such low altitudes may be explained by the occurrence of the Harmattan winds in the region during the 

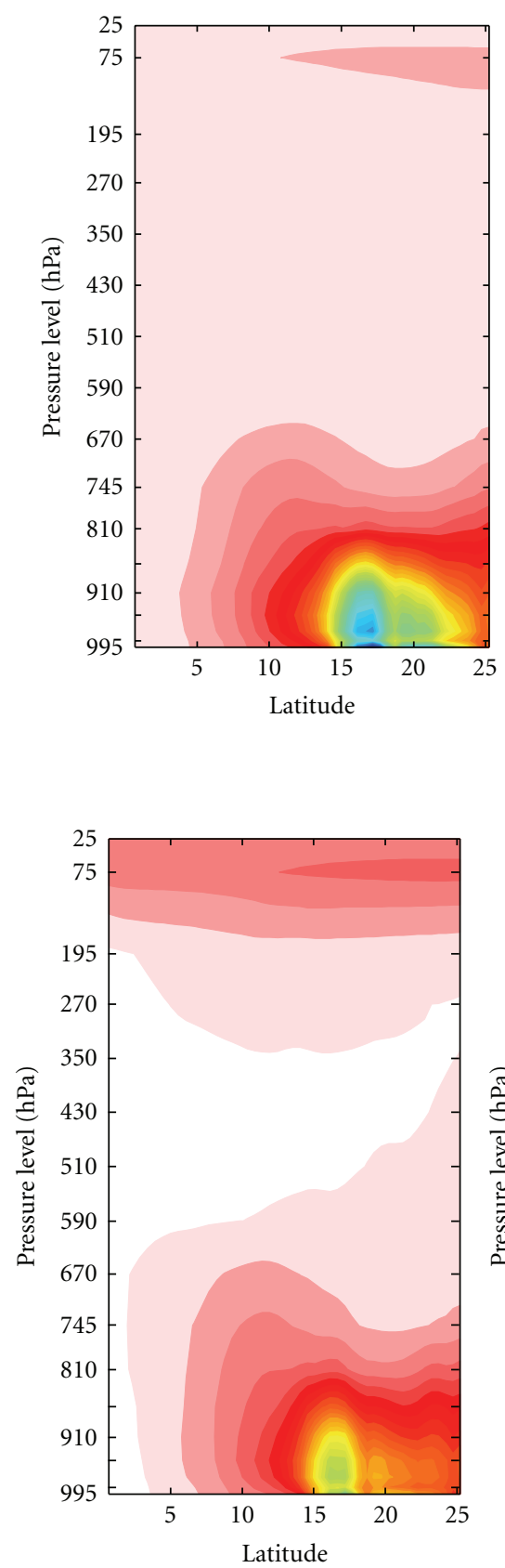

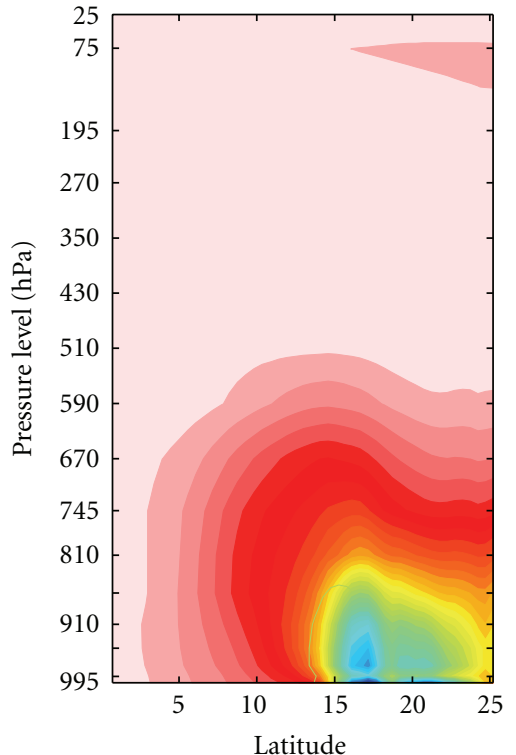

(a)
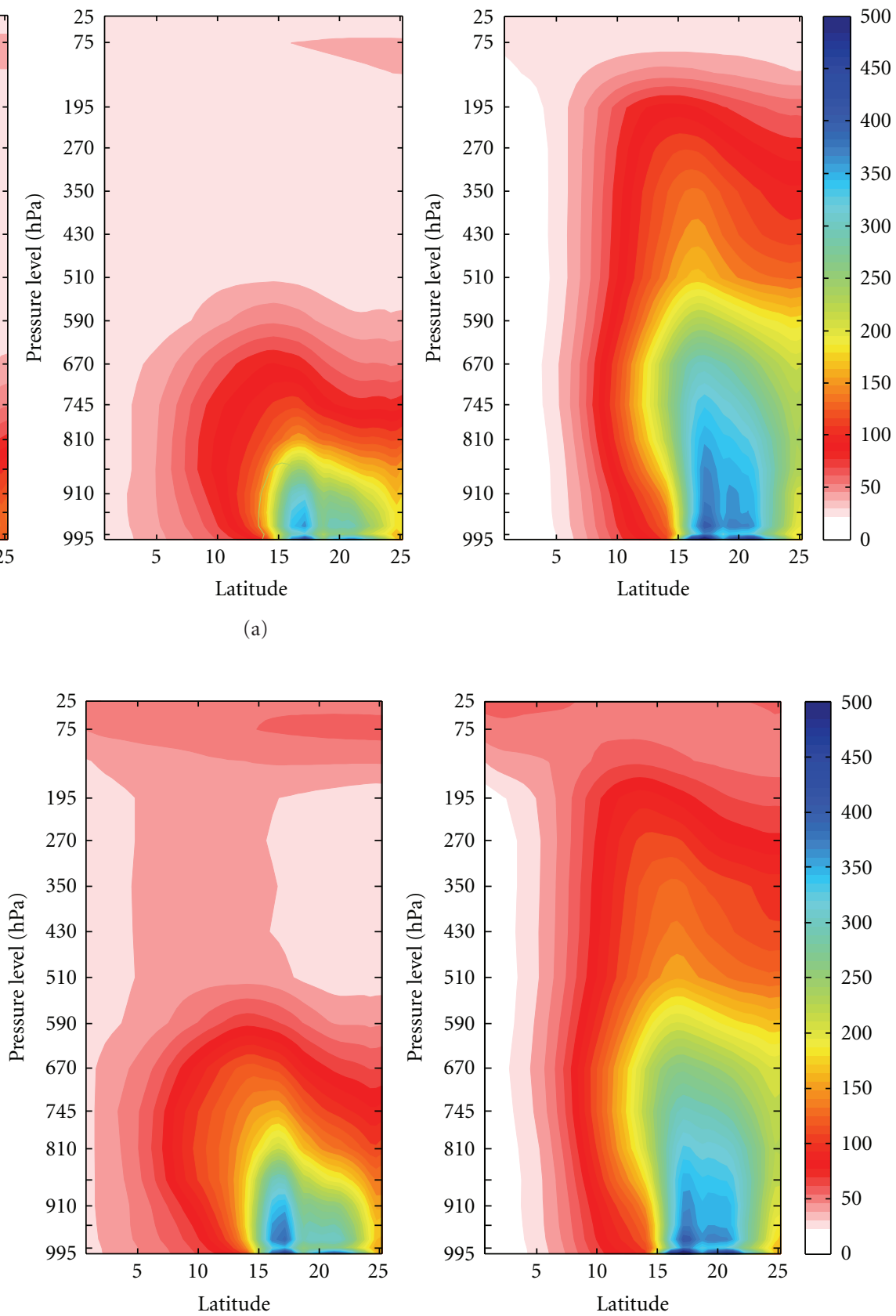

(b)

b)

FIgURE 8: Meridian profile of mean desert dust concentrations in $\mu \mathrm{g} / \mathrm{kg}$ average between $66^{\circ} \mathrm{W}$ and $23^{\circ} \mathrm{E}$ for the periods "December-JanuaryFebruary (DJF)," "March-April-May (MAM)," and "June-July-August (JJA)": (a) mean values for the years 2005-2010; (b) mean values for 2010. Higher concentrations are indicated with cool colors and lower concentrations with hot colors.

period, DJF. The Harmattan is a low-altitude wind with its maximal intensity during DJF; it could be assumed to aid the transportation of dust plumes. The dust transport seemed to have been enhanced by the North-East direction of the winds, before reaching the coast towards the Gulf of Guinea. As for the period MAM, the transitional period between the dry season and the monsoon of the boreal summer, a thermal effect of low strata (between $1^{\circ}$ West and $7^{\circ}$ East) could favor the vertical rising of dust particles, explaining the relative importance of altitudes reached. Moreover, during the boreal summer, the regional atmospheric dynamic dominated by the West African monsoon may explain the altitude and trajectory followed by dust plumes. The migration of the Inter-Tropical Convergence Zone (ITCZ) around $10^{\circ} \mathrm{N}$ and the resulting dry and wet convections could favor the vertical rising of dust plumes in the troposphere. Thus, the dusts 

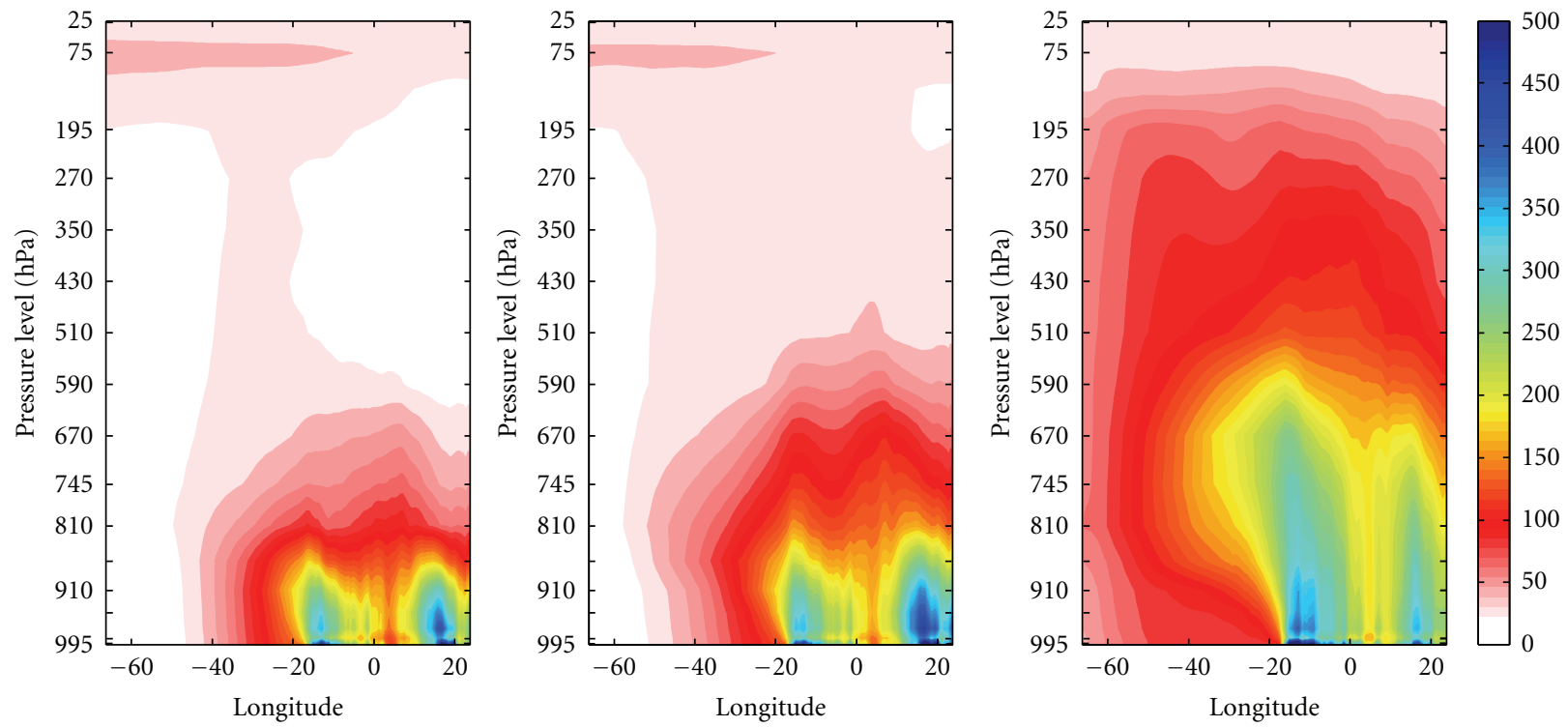

(a)
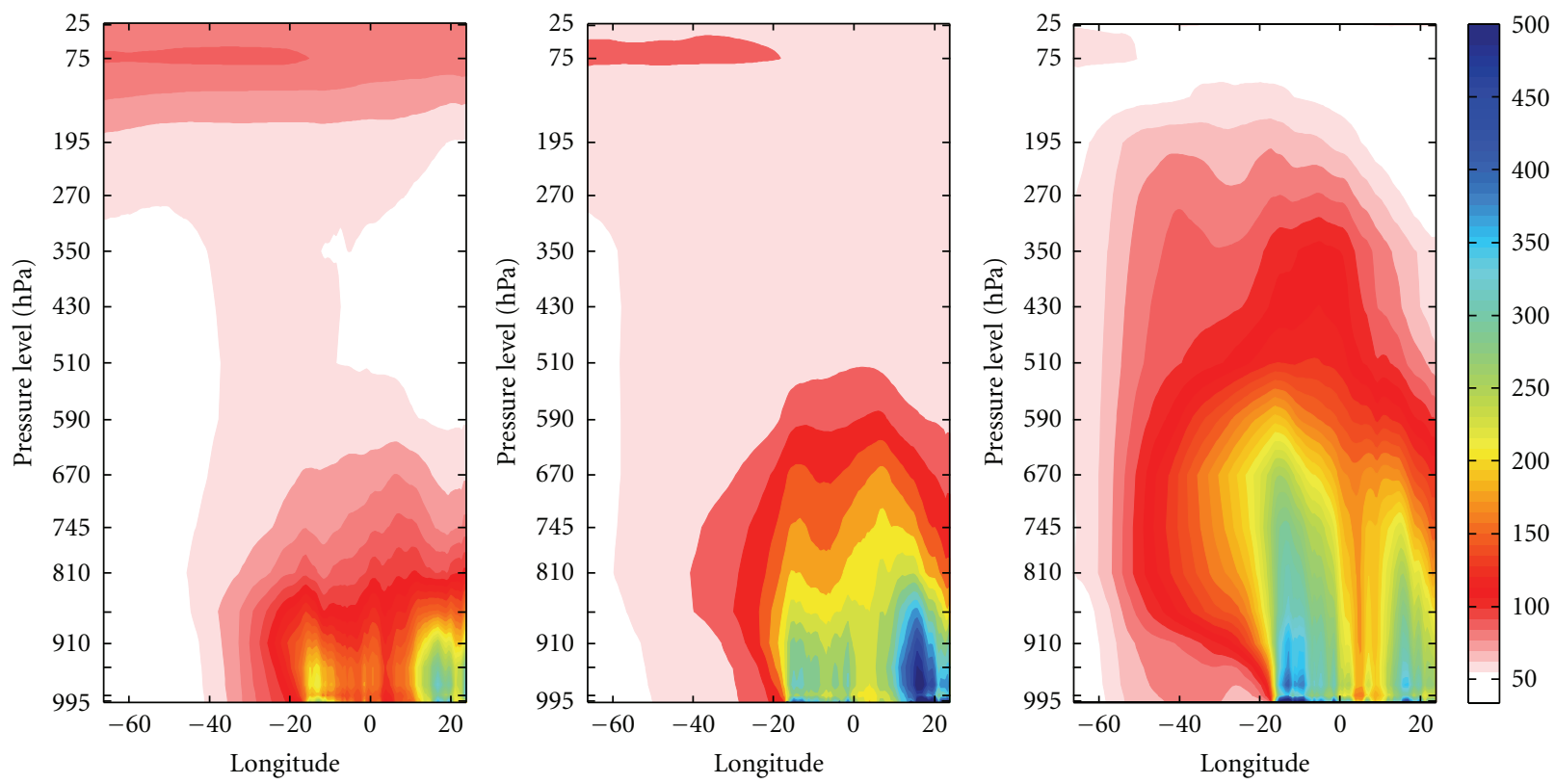

(b)

Figure 9: Zonal profile of mean desert dust concentrations in $\mu \mathrm{g} / \mathrm{kg}$ in the troposphere average between $0^{\circ} \mathrm{N}$ and $25^{\circ} \mathrm{N}$ for the periods "December-January-February (DJF)," "March-April-May (MAM)," and "June-July-August (JJA)": (a) mean values for the years 2005-2010; (b) mean values for 2010. Higher concentrations are indicated with cool colors and lower concentrations with hot colors.

emitted at the surface during the summer are ejected more higher into the atmosphere where the transport towards the Atlantic Ocean is done through the Saharan Air Layer (SAL).

The model properly represented the seasonal variability of the altitudes of dust plumes, which was in agreement with the study by Chiapello et al. [48]. In addition, the influence of the ITCZ's dynamics and dust emission mechanisms during the monsoon $[39,40]$ were also properly represented using the model. The seasonality of sources and the importance of their activity obtained using the model simulations were coherent with the results of Laurent et al. [9] who had showed that the dust sources located in the West have their maximum activities during June and July, whereas those located in the East have their during March and April. In addition, observations from MODIS, [49] showed that the Bodélé source is quasiactive during the year with maximum activities during January and March. In addition, the maximal dust emissions during the boreal summer coincided with the migration of the Inter-Tropical Front (IFT) towards the North (around $10^{\circ} \mathrm{N}$ ). This migration favored dry and wet convections that modulated dust emissions [50], which were well detected with RegCM previously shown 


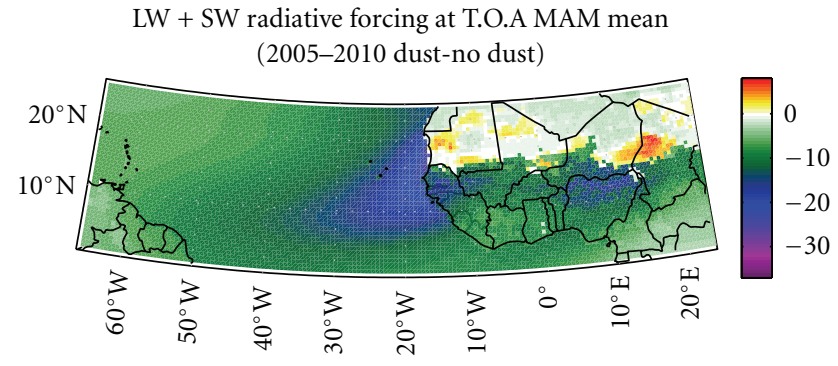

(a)

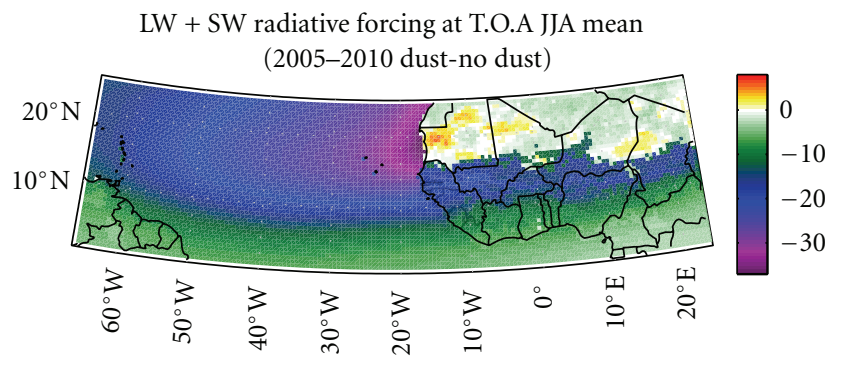

(b)

Figure 10: Solar radiation forcing (Longwave and shortwave) in $\mathrm{W} / \mathrm{m}^{2}$ due to the presence of dusts at the top of the atmosphere.

SW + LW dust radiative forcing MAM mean during 2005-2010

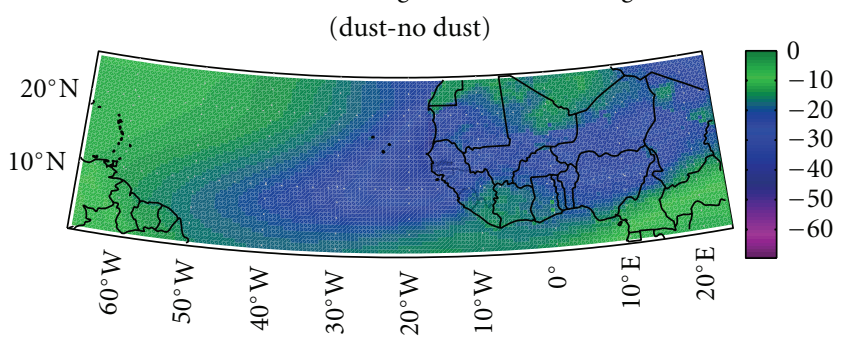

(a)
SW + LW dust radiative forcing JJA mean during 2005-2010

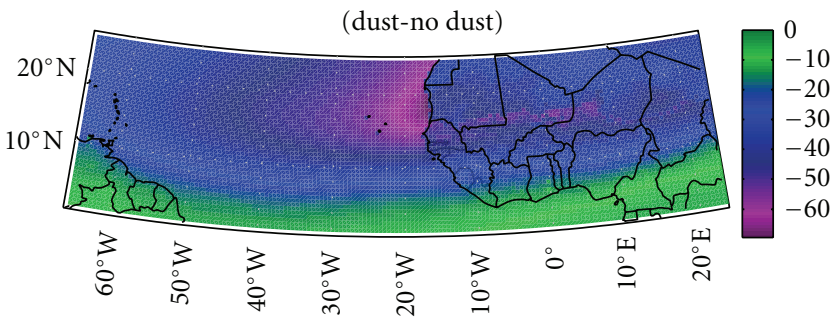

(b)

FIGURE 11: Solar radiation forcing (Longwave and shortwave) in $\mathrm{W} / \mathrm{m}^{2}$ due to the presence of dusts at the surface.

with elevated concentrations on Figures $8(\mathrm{~b})$ and $9(\mathrm{~b})$. The zonal and meridian vertical profile revealed very elevated dust concentrations in the troposphere during the periods DJF and MAM in 2010, when compared with the mean concentration found between 2005 and 2010 for the same periods.

Although the activity of the Bodélé source was less important than the mean activity during DJF between 2005 and 2010, dust concentrations in the troposphere and the stratosphere in particular were more important. During the period MAM 2010, a vertical rising observed in the vertical profiles suggested that the altitude at which dusts were transported represented an important factor for the study of the trajectories followed by dust plumes while crossing the Atlantic Ocean, as well as the distance they travel all over.

3.6. Climatic Impact of Dust. Dusts emitted during the monsoon period can significantly affect both its development and the precipitations, as they interfere with short and long wavelength radiations and modify the physical and radiative properties of clouds $[23-27,51]$. This section was devoted to the impact of dust radiative effects on surface temperatures and precipitations both during the periods (MAM) and (JJA). It is important to underline that the results presented in this section are preliminary and required further analysis that will be done in our next work.

3.6.1. Dust Radiative Forcing. The radiative forcing caused by dusts on the top of the atmosphere is presented in Figure 10.
It measured dust-induced cooling and warming events on the Earth-Atmosphere system before the climatic processes take place, that is, before any climate process interacts with the solar radiation. The results showed that over the desert, the forcing is either positive or nil, both during MAM and JJA. This may be explained by the important elevated albedo values in the region that reduced the incident solar radiation in the short wavelengths. Change in forcing sign around $15^{\circ} \mathrm{N}$ was due to the change in albedo values between the desert in the North and the Sudanian savannas in the South, and also the decrease in dust quantity from sources in the South. The results showed that the radiation forcing induced by dusts at the surface was negative both during MAM and JJA, an indication that dust can exert essential cooling effect at the surface (Figure 11). The cooling effect may suppress the vertical movement of air masses due to the lack of convective processes. If the low strata cooling and the reduction in vertical movements are strong and covering large area, it may result in a reduction in ascendant air over the extended surfaces. If this type of phenomenon occurs during the monsoon over West Africa, the reduction of the convective movement on the large scale would be sufficient to reduce significantly the moisture inflow from the Gulf of Guinea in the lower and the middle strata. Such reduction in moisture inflow towards the north may induce a delay in the onset of the monsoon and also a reduction of its intensity, leading to less precipitation.

3.6.2. Effect of Dust on Temperatures. The effect of dusts included cooling the surface during the periods JJA and 


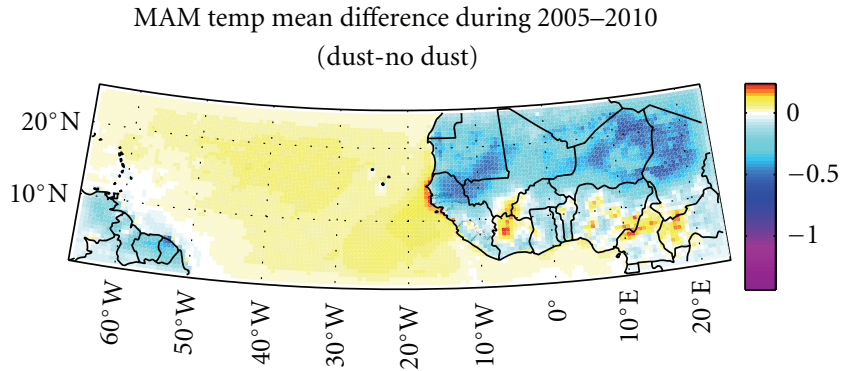

(a)

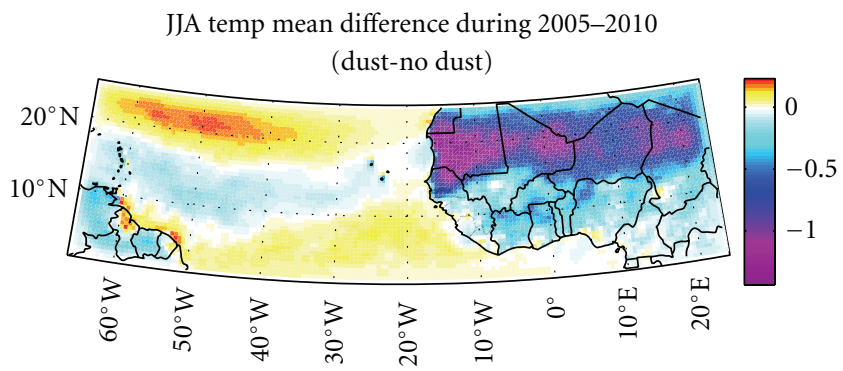

(b)

FIGURE 12: Effect of dusts on temperatures in ${ }^{\circ} \mathrm{C}$ at the surface during the months of (a) MAM and (b) JJA. Cooling is indicated with cool colors while warming with hot colors.

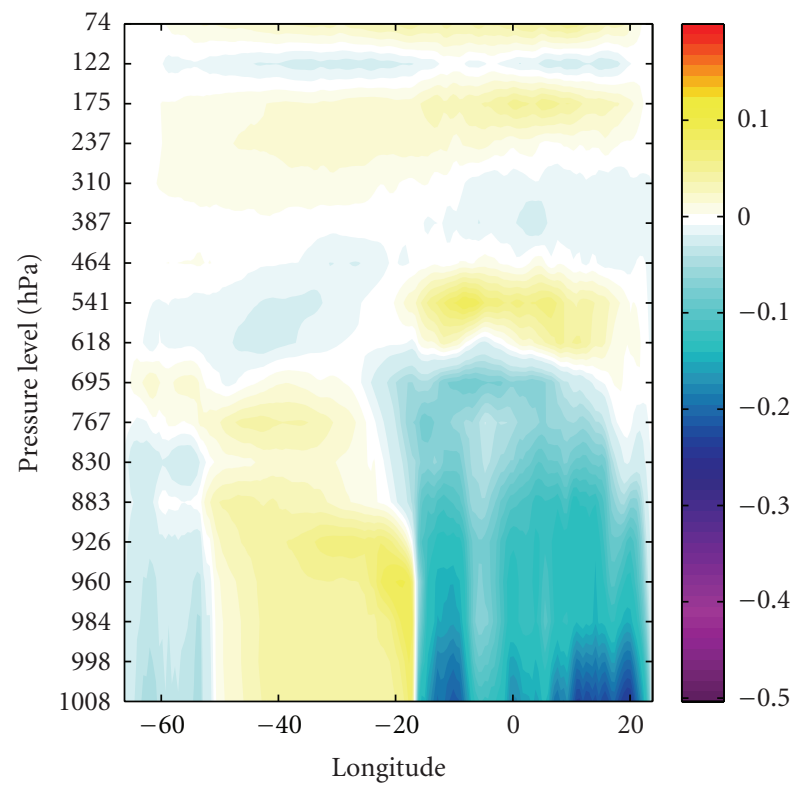

(a)

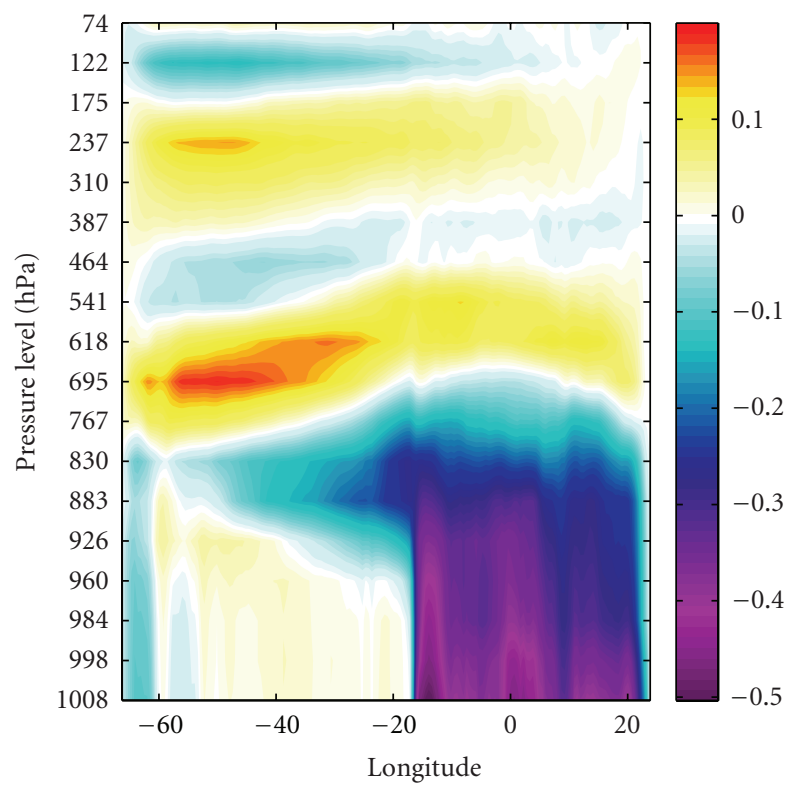

(b)

Figure 13: Zonal vertical profile of dust effect on temperatures in ${ }^{\circ} \mathrm{C}$, averaged between $0^{\circ} \mathrm{N}$ and $25^{\circ} \mathrm{N}$ during the periods (a) MAM and (b) JJA. Cooling is indicated with cool colors while warming with hot colors.

MAM (Figure 12). This cooling seemed more important during the monsoon period than the MAM period. Results reveal also warming zones, notably along the coasts, SouthWestern Burkina Faso, South-Eastern Mali, Northern Côte d'Ivoire, Western Nigeria, through to Northern-Cameroon until West of Central African Republic. Over the Ocean, there was a weak dust-induced warming. This may be attributed to dust depositional phenomena. During the monsoon period, dust-induced cooling is more important. A global cooling was observed over the Southern part of the American continent during the period MAM while warming occurred over the coasts from Guyana to Brazil (Figure 12). The zonal profile section of temperatures indicated a warming at the sea surface between longitudes $18^{\circ} \mathrm{W}$ and $50^{\circ} \mathrm{W}$, and a cooling under the domain. The cooling was observed from the surface to the middle of the troposphere around $700 \mathrm{hPa}$ (Figure 13). The meridional profile section of temperatures was in conformity with the cooling observed at the surface due to Saharan and Sahelian dust (Figure 14). The cooling at the surface was greatly accentuated and extended from the continent until the coasts during the monsoon period. However, at around $12^{\circ} \mathrm{N}$, a warming seemed to occur.

3.6.3. Effect of Dust on Precipitations. Using regional climatic modeling, some authors such as Konaré et al. [24] and Solmon et al. [25] found a reduction in precipitations, but other authors $[23,27]$ found an increase in precipitations using a global climatic model. Most of the studies conducted were focused on the monsoon period but this study considered the intermediate period MAM by analyzing the impact of dusts at a local scale outside the monsoon system. Results revealed that the Saharan and Sahelian dusts caused drying effect in the region during the two periods: MAM and JJA (Figure 15). However, there were some zones of increased precipitations even though dust quantities were low. These included Northern-Liberia, Southern-Guinea, 


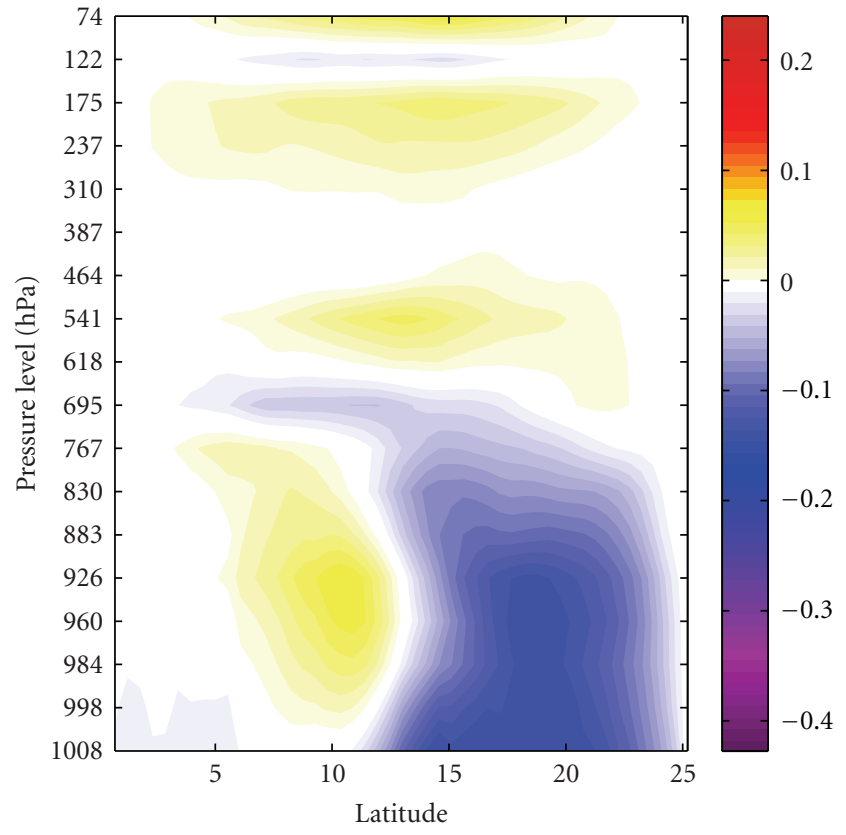

(a)

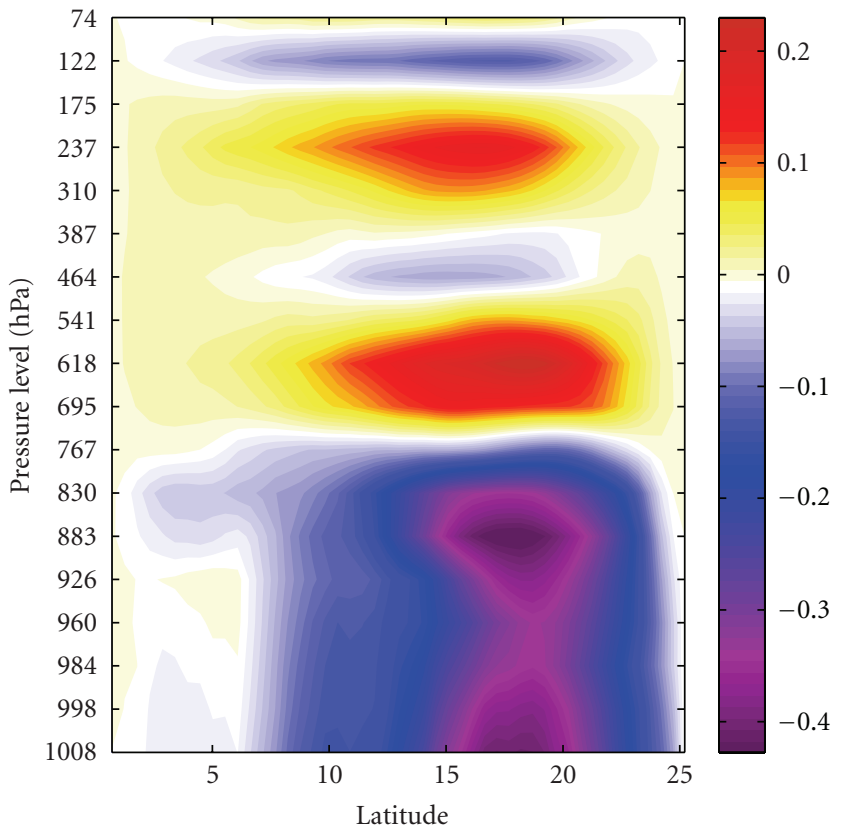

(b)

FIGURE 14: Meridian vertical profile of dust effect on temperatures in ${ }^{\circ} \mathrm{C}$, averaged between $66^{\circ} \mathrm{W}$ and $23^{\circ} \mathrm{E}$ during the periods (a) $\mathrm{MAM}$ and (b) JJA. Cooling is indicated with cool colors while warming with hot colors.

Difference de precipitation moyenne MAM (2005-2010 dust-no dust)

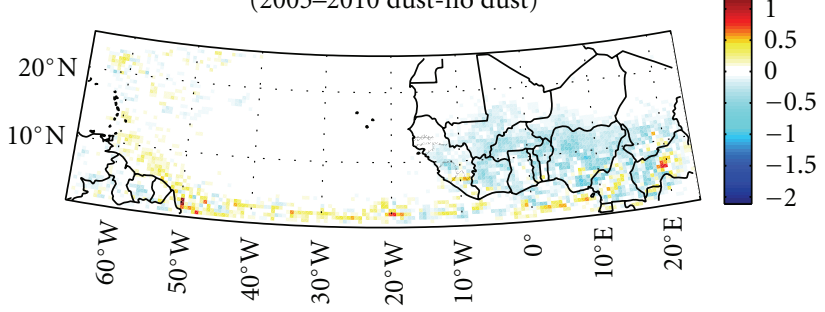

(a)

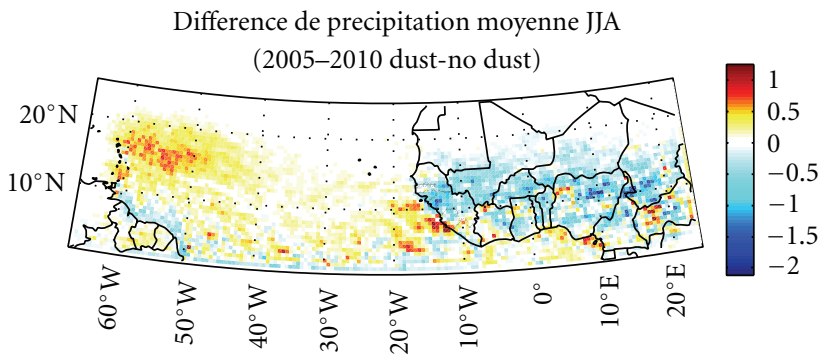

(b)

FIGURE 15: Effect of dusts on precipitations in mm/day during the period of MAM and JJA. Precipitation decrease is indicated with cool colors while increase in precipitation with hot colors.

middle of Central African Republic, Caribbean Island, and the American coasts.

During the monsoon, the dusts can induce circulation in opposite direction to the monsoon flow, which favors its weakening having the consequence of reducing precipitation. At the local level (i.e., MAM), the cooling caused can inhibit the convection and that explains the observed reduction of precipitations. These results agreed with Solmon et al. [25] who showed that dusts significantly impact on the monsoon development in West Africa by interacting with incident and reflected radiation.

\section{Conclusion}

Our study allowed analysis of simulated dust emissions from the Sahara and Sahel, using the regional climate model (RegCM). The trajectory of dust plumes were also analyzed for the months March, April, and May 2010 using the same model and other observations. The analysis revealed a seasonality of trajectories associated with the seasonality of altitudes reached by dusts plumes. The vertical profile of dust concentrations revealed a progressive increase in altitude during the period, "December-January-February (DJF)" to the period "June-July-August (JJA)," with a transition altitude during the period "March-April-May (MAM)." Indeed, during the period DJF, dust plumes flow in the low altitudes while high altitudes are reached during the period JJA. The model well captured the variability of various episodes at the African stations (Banizoumba, Cinzana, and M'Bour). However, it underestimated the peaks of AOD values compared to the observations. In the Barbados Islands, it satisfactorily reproduced the variability of AOD values even though it did not capture all the peaks shown by the AERONET observations. Part of the differences 
between the AOD values and those of the observations from AERONET, during the month of March, is probably due to the exclusion of biomass fires from this study although they were present in the West African landscape.

The study of the impact on precipitations and local temperatures of Saharan and Sahelian dusts (outside the monsoon period) indicated that dusts could exert a cooling effect in the whole region both during the period MAM and the monsoon period (JJA). This was in agreement with the studies of Konaré et al. [24] and Solmon et al. [25] for the period JJA. However, the extension over the Atlantic Ocean did not modify the results found by these previous studies. The cooling at the surface was accompanied by a decrease in local precipitations during the period (MAM) in the studied domain with the exception of some zones in Central Africa, West Africa (Southern-Guinea and NorthernLiberia), Caribbean, and South America, where increased in precipitations were observed.

Another study is currently being undertaken to take into account the emissions coming from bush fires in order to know their contributions to observed values and analyze their roles in climatic processes in West Africa and over the Atlantic Ocean.

\section{Acknowledgments}

The work was funded by START and RIPIECSA grant. All authors acknowledge the ICTP (International Centre for the Theoretical Physics) for their RegCM model, which was used for this paper.

\section{References}

[1] E. Servat, J. E. Paturel, H. Lubès, B. Kouamé, M. Ouedraogo, and J. M. Masson, "Climatic variability in humid Africa along the Gulf of Guinea. Part I: detailed analysis of the phenomenon in Cote d'Ivoire," Journal of Hydrology, vol. 191, no. 1-4, pp. 1-15, 1997.

[2] X. Zheng and E. A. B. Eltahir, "The response to deforestation and desertification in a model of West African monsoons," Geophysical Research Letters, vol. 24, no. 2, pp. 155-158, 1997.

[3] N. Brooks and M. Legrand, "Dust variability over northern Africa and rainfall in the Sahel," in Linking Climate Change to Landsurface Change, S. J. McLaren and D. Kniveton, Eds., chapter 1, pp. 1-25, Springer, New York, NY, USA, 2000.

[4] M. O. Andreae, "Climatic effects of changing atmospheric aerosol levels," in World Survey of Climatology, A. HendersonSeller, Ed., vol. 16 of Future Climates of the World, pp. 341-392, Elsevier, New York, NY, USA, 1995.

[5] R. A. Duce, "Sources, distributions, and fluxes of mineral aerosols and their relationship to climate," in Aerosol Forcing of Climate, R. J. Charson and J. Heintzenberg, Eds., pp. 43-72, John Wiley \& Sons, New York, NY, USA, 1995.

[6] L. Schultz, Jaenicke, and H. Pieter, "Sahara dust transport over the north Atlantic ocean," in Desert Dust: Origin, Characteristics, and Effect on Man, T. L. Péwé, Ed., pp. 87-100, The Geological Society of America, Boulder, Colo, USA, 1981.

[7] G. A. D'almeida, "On the variability of desert aerosol radiative characteristics," Journal of Geophysical Research, vol. 92, no. 3, pp. 3017-3026, 1987.
[8] R. Swap, M. Garstang, S. Greco, R. Talbot, and P. Kallberg, "Saharan dust in the Amazon Basin," Tellus B, vol. 44, no. 2, pp. 133-149, 1992.

[9] B. Laurent, B. Marticorena, G. Bergametti, J. F. Léon, and N. M. Mahowald, "Modeling mineral dust emissions from the Sahara desert using new surface properties and soil database," Journal of Geophysical Research D, vol. 113, no. 14, Article ID D14218, 2008.

[10] M. Legrand, A. Plana-Fattori, and C. N'Doumé, "Satellite detection of dust using the IR imagery of Meteosat 1. Infrared difference dust index," Journal of Geophysical Research D, vol. 106, no. 16, pp. 18251-18274, 2001.

[11] J. M. Prospero, P. Ginoux, O. Torres, S. E. Nicholson, and T. E. Gill, "Environmental characterization of global sources of atmospheric soil dust identified with the Nimbus 7 Total Ozone Mapping Spectrometer (TOMS) absorbing aerosol product," Reviews of Geophysics, vol. 40, no. 1, pp. 1-31, 2002.

[12] S. Engelstaedter, I. Tegen, and R. Washington, "North African dust emissions and transport," Earth-Science Reviews, vol. 79, no. 1-2, pp. 73-100, 2006.

[13] G. A. D'Almeida, "A model for Saharan dust transport," Journal of Climate \& Applied Meteorology, vol. 25, no. 7, pp. 903-916, 1986.

[14] C. Moulin, C. E. Lambert, U. Dayan et al., "Satellite climatology of African dust transport in the Mediterranean atmosphere," Journal of Geophysical Research D, vol. 103, no. 11, pp. 13137-13144, 1998.

[15] J. M. Prospero and P. J. Lamb, "African droughts and dust transport to the Caribbean: climate change implications," Science, vol. 302, no. 5647, pp. 1024-1027, 2003.

[16] I. Borbely-Kiss, A. Z. Kiss, E. Koltay, G. Szabo, and L. Bozó, "Saharan dust episodes in Hungarian aerosol: elemental signatures and transport trajectories," Journal of Aerosol Science, vol. 35, no. 10, pp. 1205-1224, 2004.

[17] P. L. Israelevich, E. Ganor, Z. Levin, and J. H. Joseph, "Annual variations of physical properties of desert dust over Israel," Journal of Geophysical Research D, vol. 108, no. 13, article 4381, pp. 1-9, 2003.

[18] T. Y. Tanaka, Y. Kurosaki, M. Chiba et al., "Possible transcontinental dust transport from North Africa and the Middle East to East Asia," Atmospheric Environment, vol. 39, no. 21, pp. 3901-3909, 2005.

[19] P. Alpert and E. Ganor, "Sahara mineral dust measurements from TOMS: comparison to surface observations over the Middle East for the extreme dust storm, March 14-17, 1998," Journal of Geophysical Research D, vol. 106, no. 16, pp. 1827518286, 2001.

[20] H. Liao and J. H. Seinfeld, "Radiative forcing by mineral dust aerosol: sensitivity to key variables," Journal of Geophysical Research D, vol. 103, no. 24, pp. 31,637-31,645, 1998.

[21] D. Tanré, J. Haywood, J. Pelon et al., "Measurement and modeling of the Saharan dust radiative impact: overview of the Saharan Dust Experiment (SHADE)," Journal of Geophysical Research D, vol. 108, no. 18, pp. 1-12, 2003.

[22] IPCC (International Panel on Climate Change), "Fourth assessment report: climate change 2007 (AR4)," in Contribution of Working Group I: The Physical Science Basis, Cambridge University Press, Cambridge, UK, 2007.

[23] K. M. Lau, K. M. Kim, Y. C. Sud, and G. K. Walker, "A GCM study of the response of the atmospheric water cycle of West Africa and the Atlantic to Saharan dust radiative forcing," Annales Geophysicae, vol. 27, no. 10, pp. 4023-4037, 2009.

[24] A. Konaré, A. S. Zakey, F. Solmon et al., "A regional climate modeling study of the effect of desert dust on the West African 
monsoon," Journal of Geophysical Research D, vol. 113, no. 12, Article ID D12206, 2008.

[25] F. Solmon, M. Mallet, N. Elguindi, F. Giorgi, A. Zakey, and A. Konaré, "Dust aerosol impact on regional precipitation over western Africa, mechanisms and sensitivity to absorption properties," Geophysical Research Letters, vol. 35, no. 24, Article ID L24705, 2008.

[26] M. Yoshioka, N. M. Mahowald, A. J. Conley et al., "Impact of desert dust radiative forcing on sahel precipitation: relative importance of dust compared to sea surface temperature variations, vegetation changes, and greenhouse gas warming," Journal of Climate, vol. 20, no. 8, pp. 1445-1467, 2007.

[27] K. M. Kim, W. K. M. Lau, Y. C. Sud, and G. K. Walker, "Influence of aerosol-radiative forcings on the diurnal and seasonal cycles of rainfall over West Africa and Eastern Atlantic Ocean using GCM simulations," Climate Dynamics, vol. 35, no. 1, pp. 115-126, 2010.

[28] F. Giorgi, M. R. Marinucci, G. T. Bates, and G. De Canio, "Development of a second-generation regional climate model (RegCM2). Part II: convective processes and assimilation of lateral boundary conditions," Monthly Weather Review, vol. 121, no. 10, pp. 2814-2832, 1993.

[29] J. S. Pal, F. Giorgi, X. Bi et al., "Regional climate modeling for the developing world: the ICTP RegCM3 and RegCNET," Bulletin of the American Meteorological Society, vol. 88, no. 9, pp. 1395-1409, 2007.

[30] A. S. Zakey, F. Solmon, and F. Giorgi, "Development and testing of a desert dust module in a regional climate model," Atmospheric Chemistry and Physics Discussions, vol. 6, no. 2, pp. 1749-1792, 2006.

[31] D. F. Zhang, A. S. Zakey, X. J. Gao, F. Giorgi, and F. Solmon, "Simulation of dust aerosol and its regional feedbacks over East Asia using a regional climate model," Atmospheric Chemistry and Physics, vol. 9, no. 4, pp. 1095-1110, 2009.

[32] F. Giorgi and G. T. Bates, "The climatological skill of a regional model over complex terrain," Monthly Weather Review, vol. 117, no. 11, pp. 2325-2347, 1989.

[33] R. Dickinson, A. Henderson-Sellers, and P. Kennedy, "Biosphere-atmosphere transfer scheme (bats) version le as coupled to the NCAR community climate model," Technical Report National Center for Atmospheric Research, 1993.

[34] L. Zobler, "A world soil file for global climate modeling," NASA-Technical Memorandum 87 802, 1986.

[35] J. T. Kiehl, J. J. Hack, G. B. Bonan et al., "Description of the ncar community climate model (ccm3)," Technical Report CAR/TN-420+STR National Center for Atmospheric Research, 1996.

[36] M. G. N’Tchayi, J. Bertrand, M. Legrand, and J. Baudet, "Temporal and spatial variations of the atmospheric dust loading throughout West Africa over the last thirty years," Annales Geophysicae, vol. 12, no. 2-3, pp. 265-273, 1994.

[37] K. D. Perry, T. A. Cahill, R. A. Eldred, D. D. Dutcher, and T. E. Gill, "Long-range transport of North African dust to the eastern United States," Journal of Geophysical Research D, vol. 102, no. 10, pp. 11225-11238, 1997.

[38] Y. J. Kaufman, I. Koren, L. A. Remer, D. Tanré, P. Ginoux, and S. Fan, "Dust transport and deposition observed from the Terra-Moderate Resolution Imaging Spectroradiometer (MODIS) spacecraft over the Atlantic Ocean," Journal of Geophysical Research D, vol. 110, no. 10, article D10S12, pp. $1-16,2005$.

[39] P. Tulet, M. Mallet, V. Pont, J. Pelon, and A. Boone, "The 7-13 March 2006 dust storm over West Africa: generation, transport, and vertical stratification," Journal of Geophysical Research D, vol. 113, no. 23, Article ID D00C08, 2008.

[40] D. B. Karam, C. Flamant, P. Knippertz et al., "Dust emissions over the Sahel associated with the West African monsoon intertropical discontinuity region: a representative casestudy," Quarterly Journal of the Royal Meteorological Society, vol. 134, no. 632, pp. 621-634, 2008.

[41] J. M. Prospero and T. N. Carlson, "Saharan air outbreaks over the tropical North Atlantic," Pure and Applied Geophysics, vol. 119, no. 3, pp. 677-691, 1981.

[42] J. M. Prospero and R. T. Nees, "Impact of the North African drought and El Nino on mineral dust in the Barbados trade winds," Nature, vol. 320, no. 6064, pp. 735-738, 1986.

[43] C. Jones, N. Mahowald, and C. Luo, "The role of easterly waves on African desert dust transport," Journal of Climate, vol. 16, pp. 3617-3628, 2003.

[44] C. Jones, N. Mahowald, and C. Luo, "Observational evidence of African desert dust intensification of easterly waves," Geophysical Research Letters, vol. 31, no. 17, article L17208, 4 pages, 2004.

[45] A. Smirnov, B. N. Holben, D. Savoie et al., "Relationship between column aerosol optical thickness and in situ ground based dust concentrations over Barbados," Geophysical Research Letters, vol. 27, no. 11, pp. 1643-1646, 2000.

[46] C. Flamant, C. Lavaysse, M. C. Todd, J. P. Chaboureau, and J. Pelon, "Multl-platform observations of a springtime case of Bodélé and Sudan dust emission, transport and scavenging over West Africa," Quarterly Journal of the Royal Meteorological Society, vol. 135, no. 639, pp. 413-430, 2009.

[47] R. A. Duce, "The impact of atmospheric nitrogen, phosphorus and iron species on marine biological productivity," in The Role of Air-Sea Exchange in Geochemical Cycling, P. BuatMenard, Ed., pp. 497-529, 1986.

[48] I. Chiapello, G. Bermagetti, L. Gomes, B. Chatenet, F. Dulac, and E. S. Suares, "An additional low layer transport of Sahelian and Saharan dust over the north-eastern tropical Atlantic," Geophysical Research Letters, vol. 22, no. 23, pp. 3191-3194, 1995.

[49] R. Washington and M. C. Todd, "Atmospheric controls on mineral dust emission from the Bodélé depression, chad: the role of the low level jet," Geophysical Research Letters, vol. 32, no. 17, Article ID L17701, pp. 1-5, 2005.

[50] S. Engelstaedter and R. Whasington, "Atmospheric controls on the annual cycle of North African dust," Journal of Geophysical Research, vol. 112, Article ID D03103, 14 pages, 2007.

[51] R. L. Miller, I. Tegen, and J. Perlwitz, "Surface radiative forcing by soil dust aerosols and the hydrologic cycle," Journal of Geophysical Research D, vol. 109, no. 4, article D04203, 24 pages, 2004. 

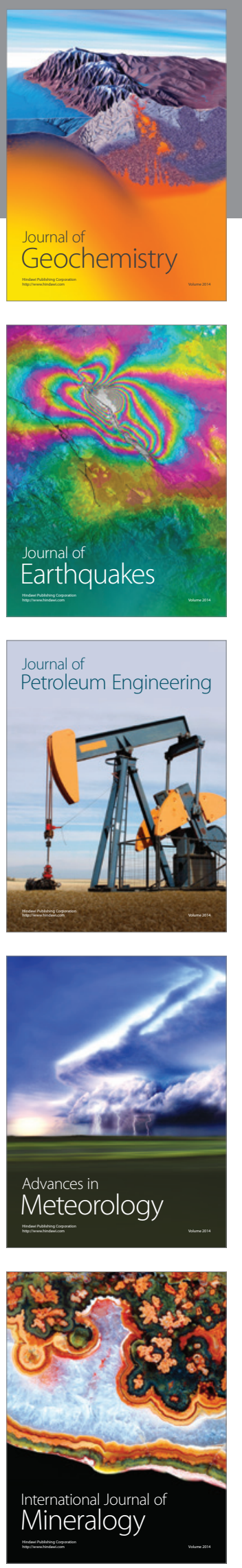
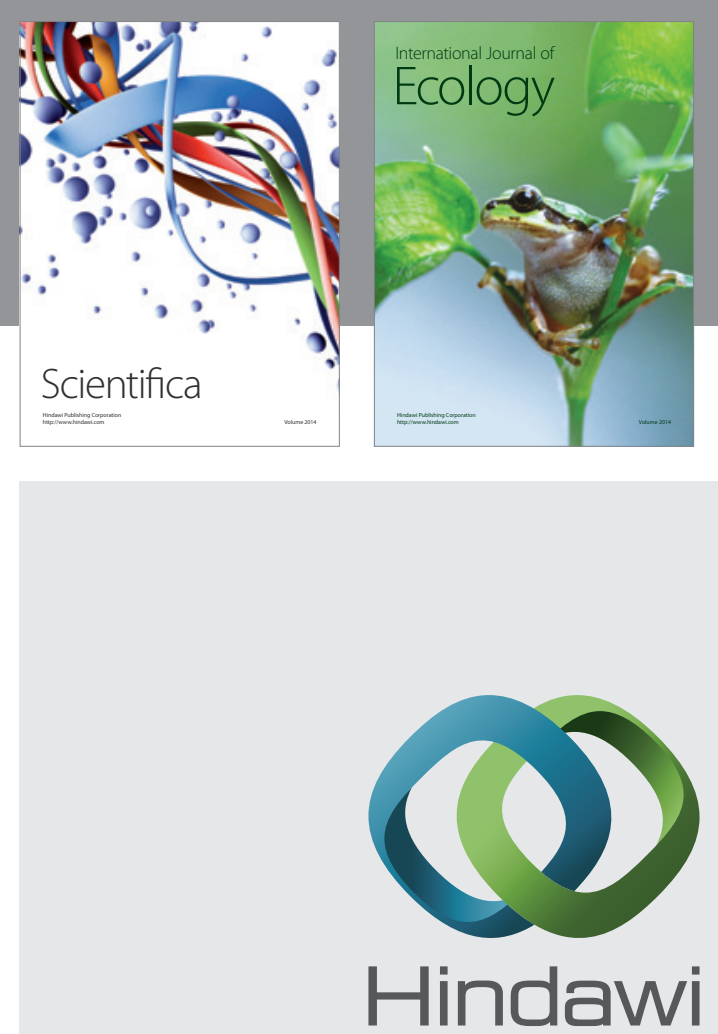

Submit your manuscripts at http://www.hindawi.com
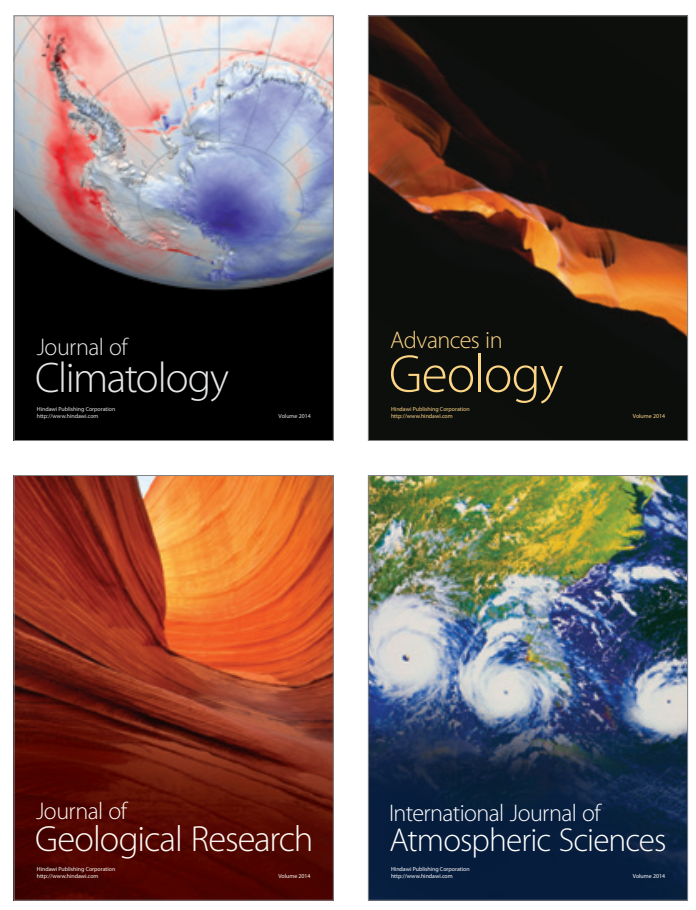
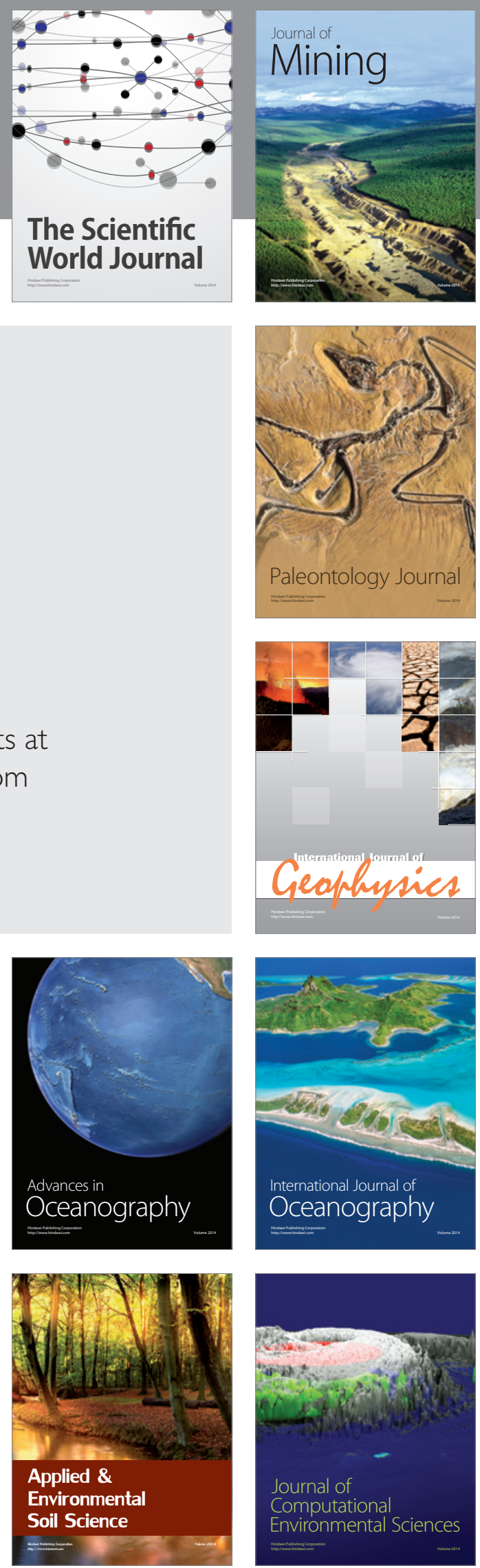